\title{
ORNL/NCEDR-8
}

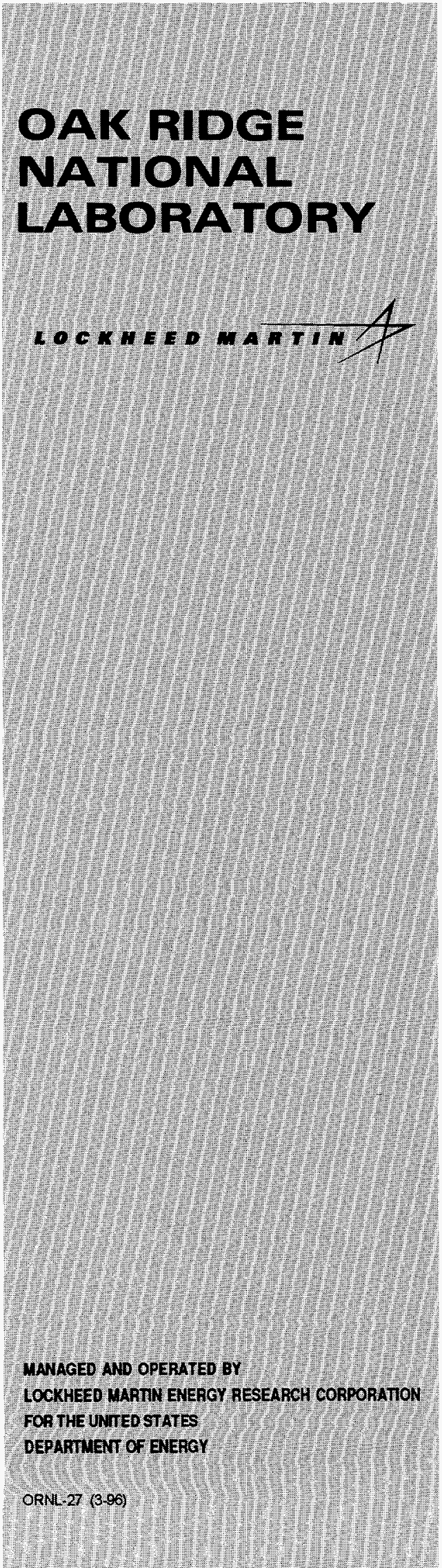

\section{CONTRIBUTIONS TO SUSTAINABILITY BY COMMUNITIES AND INDIVIDUALS: PROBLEMS AND PROSPECTS}

\author{
Bruce E. Tonn \\ Donald G. MacGregor \\ RECEIVED \\ NOV 251998 \\ OSTI
}




\section{DISCLAIMER}

This report was prepared as an account of work sponsored by an agency of the United States Government. Neither the United States Government nor any agency thereof, nor any of their employees, make any warranty, express or implied, or assumes any legal liability or responsibility for the accuracy, completeness, or usefulness of any information, apparatus, product, or process disclosed, or represents that its use would not infringe privately owned rights. Reference herein to any specific commercial product, process, or service by trade name, trademark, manufacturer, or otherwise does not necessarily constitute or imply its endorsement, recommendation, or favoring by the United States Government or any agency thereof. The views and opinions of authors expressed herein do not necessarily state or reflect those of the United States Government or any agency thereof. 


\section{DISCLAIMER}

Portions of this document may be illegible in electronic image products. Images are produced from the best available original document. 


\title{
CONTRIBUTIONS TO SUSTAINABILITY BY COMMUNITIES AND INDIVIDUALS: PROBL,EMS AND PROSPECTS
}

\author{
Bruce Tonn \\ Oak Ridge National Laboratory \\ P.O. Box 2008 \\ Oak Ridge, Tennessee 37831-6207 \\ Donald MacGregor \\ MacGregor-Bates, Inc. \\ and \\ Decision Science Research Institute (Decision Research) \\ P.O. Box 10105 \\ Eugene, Oregon 97440 \\ Prepared by the \\ OAK RIDGE NATIONAL LABORATORY \\ Oak Ridge, Tennessee 37831 \\ managed by \\ LOCKHEED MARTIN ENERGY RESEARCH CORPORATION \\ for the \\ U.S. DEPARTMENT OF ENERGY \\ under contract DE-AC05-96OR22464
}





\section{TABLE OF CONTENTS}

EXECUTIVE SUMMARY $\ldots \ldots \ldots \ldots \ldots \ldots \ldots \ldots \ldots \ldots \ldots \ldots \ldots$

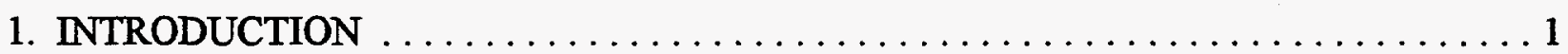

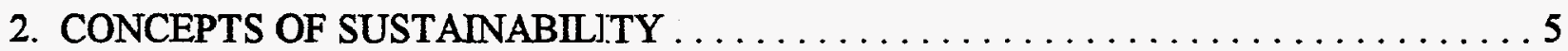

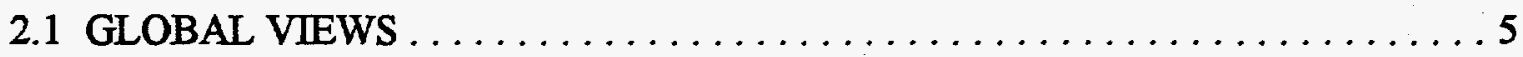

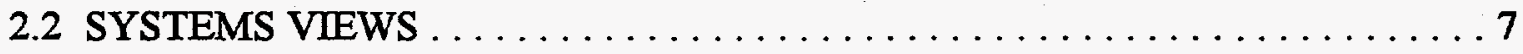

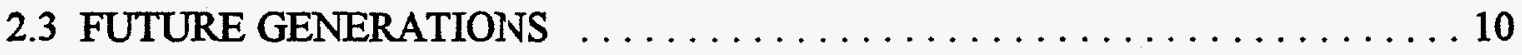

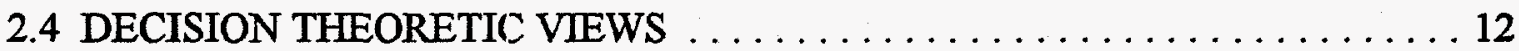

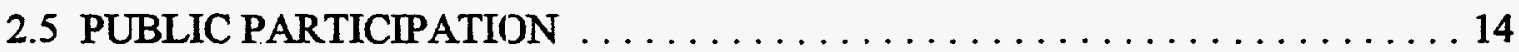

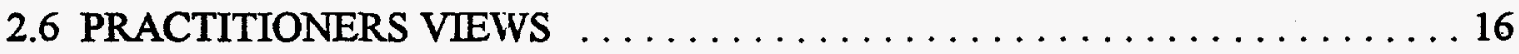

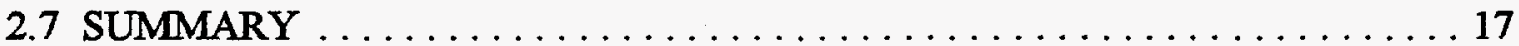

3. THINKING GLOBALLY, ACTING LOCALLY: POTENTIAL DISCONNECTS $\ldots \ldots 19$

3.1 GLOBAL PRESCRIPTIONS TO LOCAL GOALS $\ldots \ldots \ldots \ldots \ldots \ldots \ldots$

3.2 COMMUNITY EMPOWERMENT $\ldots \ldots \ldots \ldots \ldots \ldots \ldots \ldots \ldots \ldots \ldots \ldots \ldots$

3.3 EXTERNAL INFLUENCES ON COMMUNITIES $\ldots \ldots \ldots \ldots \ldots \ldots \ldots 23$

3.4 EVERYDAY CONSTRAINTS ON COMMUNITIES $\ldots \ldots \ldots \ldots \ldots \ldots 26$

3.5 ECONOMIC DEVELOPMENT VALUES AND GOALS $\ldots \ldots \ldots \ldots \ldots 27$

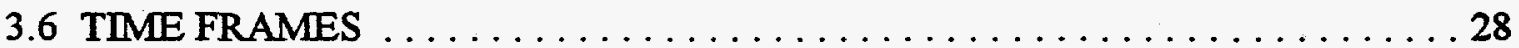

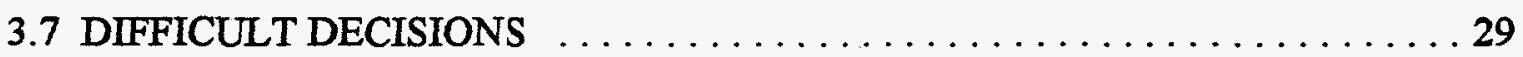

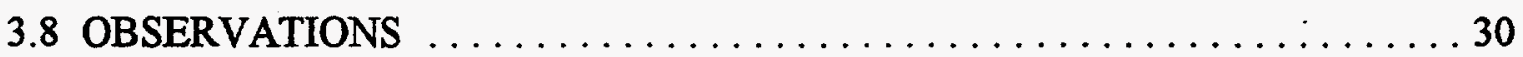

4. CONSTRAINTS ON INDIVIDUALS' SUSTAINABILITY EFFORTS $\ldots \ldots \ldots \ldots \ldots 33$

4.1 GLOBAL PRESCRIPTIONS TO INDIVIDUAL GOALS $\ldots \ldots \ldots \ldots \ldots \ldots 34$

4.2 INDIVIDUAL EMPOWJERMENT $\ldots \ldots \ldots \ldots \ldots \ldots \ldots \ldots \ldots \ldots \ldots \ldots \ldots \ldots$

4.3 EXTERNAL INFLUENCES ON INDIVIDUALS $\ldots \ldots \ldots \ldots \ldots \ldots \ldots$

4.4 INDIVIDUAL VALUES AND GOALS $\ldots \ldots \ldots \ldots \ldots \ldots \ldots \ldots \ldots \ldots \ldots \ldots$

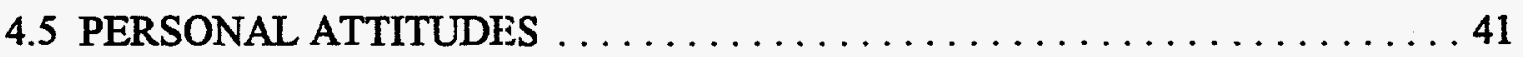

4.6 DEFINITIONS OF WELL-BEING $\ldots \ldots \ldots \ldots \ldots \ldots \ldots \ldots \ldots \ldots \ldots$

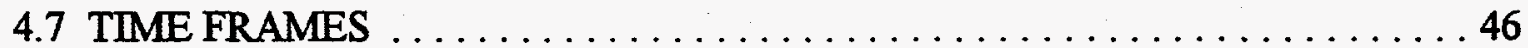

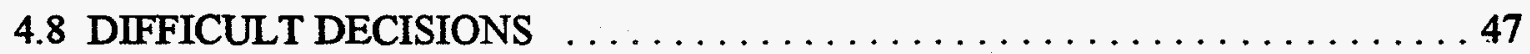

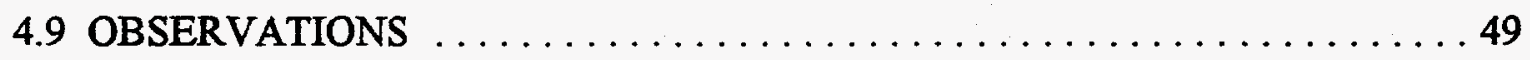




\section{TABLE OF CONTENTS (Continued)}

5. CONCLUDING OBSERVATIONS AND RECOMMENDATIONS $\ldots \ldots \ldots \ldots \ldots \ldots 51$

5.1 TRANSLATE GLOBAL SUSTAINABILITY PRESCRIPTIONS $\ldots \ldots \ldots \ldots 53$

5.2 CLARIFY RESPONSIBILITIES FOR SUSTAINABILITY $\ldots \ldots \ldots \ldots \ldots 54$

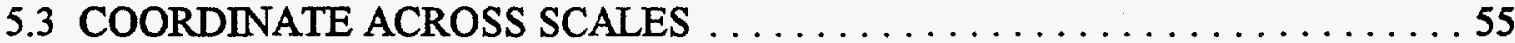

5.4 EMPOWER COMMUNITIES AND INDIVIDUALS $\ldots \ldots \ldots \ldots \ldots \ldots \ldots 6$

5.5 INTEGRATE COMMUNITY AND INDIVIDUAL SUSTAINABILITY

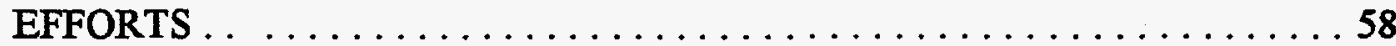

5.6 REFRAME SUSTAINABILITY PRESCRIPTIONS $\ldots \ldots \ldots \ldots \ldots \ldots .59$

5.7 DEVELOP BETTER SUSTAINABILITY INDICATORS $\ldots \ldots \ldots \ldots \ldots .59$

5.8 IMPLEMENT EVALUATION PROGRAMS $\ldots \ldots \ldots \ldots \ldots \ldots \ldots \ldots 6 . \ldots \ldots$

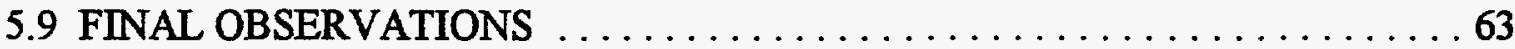

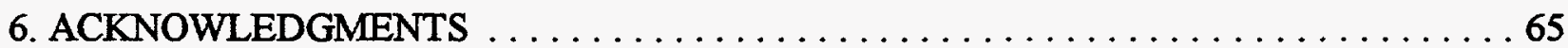

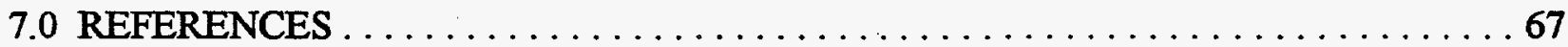




\section{EXECUTIVE SUMMARY}

This report examines relationships between a comprehensive set of definitions of and viewpoints on the concept of sustainability and the abilities of communities and individuals in the United States to meet the behavioral prescriptions inherent in these definitions and viewpoints. This research is timely because sustainability is becoming a cornerstone of national and international environmental strategies designed to simultaneously achieve environmental, economic, and social goals. In the United States, many communities have adopted sustainability principles as the foundation for both their environmental protection efforts and their socioeconomic development initiatives. This research is important because it highlights serious problems communities and individuals may have in achieving sustainability expectations, and illustrates how much work is needed to help communities and individuals overcome numerous considerable and complex constraints to sustainability.

For this analysis, definitions of sustainability were drawn from a broad range of sources. The definitions are generally wide-ranging and multidisciplinary in nature. The definitions are grouped into global views, systems frameworks views, future generations concerns, decision theoretic views, public participation prescriptions, and practitioner views. Important aspects from the numerous definitions and viewpoints were distilled and synthesized into the following list of sustainability prescriptions:

- limit resource use - e.g., energy, water, minerals;

- reduce pollution;

- recycle;

- control population;

- protect biodiversity;

- constrain the pace of change;

- limit consumerism; 
- conserve land;

- practice strong democracy;

- achieve intra- and inter-generational equity;

- meet basic human needs;

- adopt sustainable personalities; and

- implement proper decision-making heuristics, such as the precautionary principle.

These behavioral prescriptions cannot be easily met by communities. One problem is that many global prescriptions have not been translated into specific goals for communities (e.g., how much land and water should each community conserve?). A second problem is that many of the prescriptions are beyond the power of communities to enact (e.g., communities do not have the power to control human fertility, and only few tools to control energy use per capita, and consumption of goods and materials). A third problem is that strong external influences (especially economic forces) buffet communities to such a degree that short-term survivability often takes precedence over long-term sustainability. Everyday institutional problems (e.g., employee turnover), conflicts between value systems based on economic growth and sustainability concepts that emphasize minimalism and conservation, and time frames for sustainability that are beyond normal political time frames all cause difficulties for communities trying to meet sustainability prescriptions. These six problems add complexity to an already very challenging decision-making task that must somehow encompass large uncertainties, long time frames, a multiplicity of values, concerns for future generations and other species, and environmental ethics all within a multi-scalar systems framework.

Individuals also face difficulties in meeting sustainability behavioral prescriptions. Global sustainability prescriptions are typically not expressed in terms relevant to individual behavior (e.g., how much land should an individual conserve?) nor consistent with behavioral motivations (people respond better to to-dos rather than don't dos). There are some prescriptions that individuals are not empowered to achieve by themselves, such as constraining the pace of change. In addition, external socioeconomic influences often act in concert to severely constrain the time, 
money, attention, and goodwill that individuals can direct toward those behavioral prescriptions within their abilities to achieve. Personal attitudes about the environment, the future of humanity, human well-being and the quality of life are highly diverse, variable, and at times internally inconsistent, which can constrain proactive behaviors. Lastly, the time frames implied within frameworks of sustainability are, for the most part, beyond those individuals normally consider.

To address these problems, the report concludes with the following eight recommendations:

- Translate global sustainability prescriptions into guidelines, if not targets, for communities and individuals;

- Specify responsibilities for meeting sustainability prescriptions by each level of social organization, from international institutions to individuals;

- Coordinate decision making and information flows about sustainability across different levels of scale;

- Improve empowerment of communities and individuals to meet sustainability responsibilities;

- Integrate community and individual sustainability efforts better;

- Reframe sustainability prescriptions aimed at communities and individuals to improve their understandability and relevance;

- Develop and implement better indicators of sustainability at the community and individual levels; and

- Implement vigorous and rigorous evaluation, learning, and societal memory programs to support improved sustainability decision making over the very long term.

As a final point, it must be remembered that sustainability is an evolving concept. There is no universally agreed upon definition. This uncertainty is only magnified when sustainability is considered at the community and individual levels. It is possible, even probable, that efforts made by communities and individuals to deal with sustainability will lead to social learning which in turn will lead to improvements in our defiritions and understandings of sustainability. 


\section{INTRODUCTION}

This report examines the abilities of communities and individuals in the United States to achieve the behavioral prescriptions associated with the concept of sustainability. Lead by Chattanooga, Tennessee; Santa Monica, California; Seattle, Washington; and many others, communities across the country are initiating a wide range of sustainability programs seeking to protect both their economic futures and their environments (Concern 1998). Most typically, community-based sustainability efforts entail envisioning desired futures, establishing indicators of success or failure, working to meet indicator goals, and periodically evaluating progress toward meeting indicator goals. Community sustainability efforts depend upon active citizen participation and effective community programs (Okubo 1997). Community success often depends upon the efforts of individual citizens who, among other things, recycle their household wastes, reduce their use of water, and vote to allocate community funds to sustainability programs. It is an open question, and the central theme of this report, whether communities and individuals can meet quite-substantial sustainability expectations.

Part of the problem is that there is no universally accepted definition of sustainability. Much debate centers on what sustainability is (or should be), on the quality of science that supports it, and on what policies should be implemented to achieve sustainability. Most of this debate takes place within national and international forurns, and in the international academic literature. As a result, most attention focuses on national and international issues, and to a large degree, how communities and individuals can contibute. What constraints they may face is often ignored. This research contributes to the debate by focusing needed attention on communities and individuals and on their roles in meeting sustainability objectives. It also contributes to the definition of sustainability by highlighting the need to link global to local scales in coordinated manners to foster effective sustainability efforts. 
To guide our analysis, we draw a distinction between communities and individuals. This is done, in part, because communities and individuals can contribute to meeting sustainability prescriptions in different ways and because they face somewhat different problems in meeting sustainability prescriptions. Also, the distinction highlights the symbiotic relationships between individuals and the communities in which they live. Though in a countable sense, communities are collections of individuals, communities are not homogeneous with respect to individuals. That is, a community is a sociopolitical construct that comprises individuals who are free to think and act in ways that may be inconsistent with some concept of the community. For example, some individuals within a community may hold greater allegiance, or attachment, to their community than others, or may be more involved in community affairs and, therefore, have a greater stake in implementing community goals and objectives at a personal level. Therefore, our analysis looks at both constraints on communities and on individuals to act in ways that are consistent with sustainability prescriptions.

Section 2 initiates this report with an assessment of the term 'sustainability.' Definitions and viewpoints from a wide range of sources are summarized and interpreted. It is found that the term means many things to many people. Prescriptions associated with the concept are quite numerous and in aggregation appear daunting for communities and citizens alike. Section 2 concludes with a distilled and synthesized list of prescriptions that is used as the basis for the constraints assessments in the remainder of the report.

Section 3 assesses barriers that may inhibit communities from achieving global sustainability prescriptions. The fundamental question is whether communities have the guidance and tools to "think globally, act locally." Section 4 focuses on citizens and probes the question of whether individuals can "Think Globally, Act Individually." Because communities and individuals essentially face similar categories of challenges with respect to satisfying global sustainability prescriptions, the two sections possess similar subsection headings and discussions. 
Sections 3 and 4 indicate that communities and individuals face numerous significant problems in meeting sustainability prescriptions. These problems include: a disconnect between global notions of sustainability and local goals; constraints that act upon individuals' ability to behave in sustainable manners; and critical limitations to communities' and individuals' abilities to control their external environments. These observations are the basis for a discussion on the future of community and individual sustainability efforts in Section 5 . This section concludes with eight general recommendations. 


\section{CONCEPTS OF SUSTAINABILITY}

"A philosophy of the 'conserver society' (Valaskakis et al. 1975), of 'small is beautiful' (Schumacher 1973), of 'joyous austerity' (Dansereau 1975) is offered as a grid upon which to project the image of 'Only One Earth' (Ward and Dubos 1972) as a means of insuring 'Our Common Future' (WCED 1987)." Comments on sustainability by Dansereau 1990:58.

This section reviews numerous concepts and definitions of sustainability. It is difficult to categorize the various definitions. As the above cuote illustrates, most discussions of sustainability are multi-disciplinary in nature and subsurne broad ranges of spatial and temporal scale. In addition, it is clear that sustainability is a normative concept that people write about based on personal beliefs, and professional backgrounds and experiences. Because of these factors, there is no universally agreed upon definition of sustainability. To provide a framework for thinking about sustainability, this section organizes the results of the literature review as follows: global views; systems views; future generations; decision theoretic views; public participation; and practitioner views. In Sections 3 and 4, these multifaceted views of sustainability will be examined for their relevance to both community-based and individual decision making and behavior, respectively.

\subsection{GLOBAL VIEWS}

One of the most global and materials-sophisticated approaches to sustainability is promoted by The Natural Step (Holmberg et al. 1996). Their four principles of sustainability are:

- substances extracted from the lithosphere must not systematically accumulate in the ecosphere;

- society-produced substances must not systematically accumulate in the ecosphere; 
- the physical conditions for production and diversity within the ecosphere must not be systematically deteriorated; and

- the use of resources must be effective and just with respect to meeting human needs.

The first three principles are global in nature, mostly related to material matters, and to be met must receive attention at a global level while being implemented in a myriad of manners at the community, individual, and, especially, corporate levels. As noted above, most definitions are interdisciplinary and this one is no exception, as the fourth principle combines a decision-making perspective - use of resources must be 'effective' - and a value-oriented perspective - use of resources must be 'just.'

Another global materialistic prescription which can be added to the three above relates to energy use. Usually known as 'the entropy principle,' this principle states that life on earth should not use more energy each day than is supplied by the sun each day (e.g., see Georgescu-Roegen 1971). Patterns of energy use which violate this principle are not sustainable in the very long-run.

Daly (1990) presents three principles for sustainability that seem to combine the entropy principle and the ideas put forth by The Natural Step. These principles are:

- nonrenewable resources should not be depleted at rates higher than the development rate of renewable substitutes;

- renewable resources should not be exploited at a rate higher than their regeneration level; and

- the absorption and regeneration capacity of the natural environment should not be exceeded.

Many viewpoints on sustainability focus solely on global perspectives of ecosystems. For example, Chapin et al. (1996) state that a sustainable ecosystem is one that, over the normal cycle of disturbance events, maintains its characteristic diversity of major functional groups, productivity, 
and rates of biochemical cycling. In other words, the ecosystem oscillates within stable bounds, and is characterized by a sound system of feedback loops. Sloep (1994) argues that the concept of sustainability, seen as driven by envircnmental problems brought on by human interference with the physical environment and having effects that are unacceptable with respect to individual or community norms, has changed the conceptual landscape of environmental science.

Other global views of sustainability cast a broader net over the notion of sustainability (Milbrath 1989). For example, Donella Meadows (1996) states that:

\footnotetext{
"Our rational minds tell us that a sustainable world has to be one in which renewable resources are used no faster than they regenerate; in which pollution is emitted no faster than it can be recycled or rendered harmless; in which population is at least stable, maybe decreasing; in which prices internalize all real costs; in which there is no hunger or poverty; in which there is true, enduring democracy. But what else?"
}

Others echo these general views. Randers (1994) states that "Sooner or later, the growth in the global population, resource depletion rates and negative environmental impact will have to level off. It is hoped that such stabilization will occur at a sustainable level - i.e., a level that can be maintained for generations without a decline in the quality of life." McKelvey and Rismiller (1995) believe that "Self sufficiency of water, power and minimal waste/recycle programs are key concepts for practical sustainability." Holdgate (1996) states that "The challenge is to transform a high-consumption society, with a linear flow of materials from rocks, soil and factories through households or offices to waste tips or the sea, to a low-consumption, conserver society in which materials flow in closed-loops."

\subsection{SYSTEMS VIEWS}

From these definitions, one can see how global materialistic prescriptions metamorphose into systems-related definitions of sustainability. The systems definitions are epitomized by linkages 
between system elements, values, and goals. The literature holds a surprisingly high number of systems views of sustainability, many of which are summarized by Hodge (1997). For example, Robinson (1989) lists five, interrelated and interdisciplinary systems characteristics for sustainability:

- environmental protection;

- sustainability of resource development;

- increased efficiency of resource and material use;

- social and environmental diversity, flexibility and responsibility; and

- such sociopolitical values as equity, community, participation, and autonomy.

The Canadian International Development Agency (CIDA 1991) also lists five important elements of sustainability: environmental sustainability (ecosystem integrity, biological diversity, population); economic sustainability (appropriate economic policies, efficient resource use, more equitable access to resources including gender equity, increasing productive capacity of the poor); political sustainability (human rights, democratic government, good governance); social sustainability (improved income distribution, gender equity, investing in basic health and education, emphasizing participation of the beneficiaries); and cultural sustainability (sensitivity to cultural factors, recognition of values that are conducive to development). Sadler (1988) sees sustainability as the interaction of environmental, economic, and social goals to give (1) conservation with equity; (2) environment-economy integration; and (3) community economics as if people mattered.

The Second World Conservation Strategy of the International Union for Conservation of Nature and Natural Resources, the United Nations Environment Programme, and the World Wildlife Fund (IUCN et al. 1991) state that society is ecologically sustainable when it:

- conserves ecological life-support systems and biodiversity;

- ensures that uses of renewable resources are sustainable and minimizes the depletion of nonrenewable resources; and 
- keeps within the carrying capacity of supporting ecosystems.

These kinds of systems principles can be transferred down to the level of cities (e.g., NREL 1995). For example Roger-Machart (1997) states: "A sustainable city is a city meeting the needs of its present citizens without bankrupting the resources of worldwide future generations. In other words, a sustainable city is one providing for the basic needs of all its citizens while successfully managing the environmental resources which it requires in its everyday life." This is accomplished by (1) careful management of the demand for resources; (2) maximizing circularity of resource use; and (3) maximizing the efficiency of resource use. Additionally, Haughton and Hunter (1994) state: "Sustainable cities can be defined as cities in which people and businesses continually endeavor to improve their natural, built, and cultural environments at neighborhood and regional levels, whilst working in ways which always support the goal of sustainable development."

At the level of cities, we find the first hint that communities, which by-and-large are being thought of as geographically bounded entities, may find it difficult to achieve sustainability, a theme carried out in much more depth in the next section of this report. For example, from Rees and Wackernagel (1996), we find this statement which first defines the concept of ecological footprint and then offers a conclusion: "Ecological footprint - estimate annual per capita consumption then land area appropriated per capita for each consumption item. Therefore cities are not in themselves sustainable." In other words, if one were to encapsulate a city and force it to completely meet its needs for food, water, and other necessities of human life, a city would not be able to survive. If true sustainability at a community level is not projected to be achievable, what does sustainability mean? Additionally, does this mean that sustainability is context and/or scale dependent, that it would mean different things to different cities, communities and regions?

Hodge (1997) notes that these and other system-based viewpoints on sustainability tend to encompass three main components: environment, economy, and social/cultural/community/health. The environment is conceptualized in terms of ecology, the physical environment, natural resources in conjunction with development, and physio-chemical properties. Economy is 
conceptualized in terms of productive capacity, growth, efficiency, and prosperity. The last component is conceptualized in terms of: ethnology, sociology, social systems, culture, community, health, politics and equity.

Added to these three main components should be some notion of change. Roberts (1998) tackles this head on by asking and answering: "What is sustainable development? A system that operates in equilibrium or changes slowly but in an acceptable rate. All wastes get used." Castle et al. (1997) state that sustainable development is a value in guiding change, not in finding stability. Costanza and Patten (1995) argue that sustainability can only be assessed after the fact, that it is a prediction problem more than a definition problem.

\subsection{FUTURE GENERATIONS}

As has been illustrated in several definitions above, sustainability is a value-laden concept. Probably the most famous and recognizable definition of sustainability was offered by the Bruntland Commission (WCED 1987): "Development that would meet the needs of the present without compromising the ability of future generations to meet their own needs." This definition stresses obligations to future generations and begins to develop a decision making perspective on the problem of sustainability that requires some analysis concerning what must be done to ensure fairness between present and future generations. Howarth and Norgaard (1992) make this point more explicitly: “. . . incorporating environmental values per se in decision making will not bring about sustainability unless each generation is committed to transferring to the next sufficient natural resources and capital assets to make development sustainable." Similarly, Howarth (1995) states: "It is plausible to assert that each successive generation holds a duty to ensure that the expected welfare of its offspring is no less than its own perceived well-being." Opschoor (1996) expands on these points to include fairness to other life forms: "Sustainability is related to the continuing existence of conditions favorable to life, human life in particular. It also has to do with 
fairness or equity, and to the integrity of natural systems and processes as perceived by homo sapiens."

Because obligations to future generations is a major element of the values perspective on sustainability, the following paragraphs briefly review the literature on future generations that contains additional prescriptions on decision making as applied to sustainability. One prescription is known as the fairness obligation. It concerns not imposing risks on future generations that present generations would not acceptably impose on themselves. For example, MacLean's (1981) neutrality criterion states that: "levels of risk to which future generations will be subjected will be no greater than those of present person's." Risks can include risks of premature "death owning to environmental or other preventable catastrophes" (Tonn 1987) or other risks to the quality of life. Fairness also implies an element of consent. According to Schrader-Frechette (1991), "Until or unless a risk imposition receives the consent of those who are its potential victims, it cannot be justified."

Another prescription is the obligation to maintain options. It entails giving to our posterity future worlds that are as free of man-made constraints as possible. In other words, there is a need to prevent environmental and other catastrophes "that would restrict the future of the human race by cutting off certain possible futures" (Tonn 1986). By cutting off many futures, the ability of future societies to grow and mature is reduced (Golding 1981) as is the freedom for people to "reason about means and ends and evaluate preferences, to match desires and beliefs and then act" (Gilroy 1992). Frankenfeld (1993) argues that current generations owe posterity a world as simple, controllable, and affordable as possible. Brown's (1990) Principle of Conservation of Options holds that: "Each generation should conserve the diversity of the natural and cultural resource base so that it does not unduly restrict options available to future generations...."

A third prescription is the quality of life obligation. It refers to ensuring that future generations enjoy all the most important aspects of life. From an international survey, Tough (1993) distilled these quality of life obligations to future generations: peace and security, a healthy environment, a 
small risk of preventable catastrophe, stable governance, conservation of knowledge, a good life for children, and opportunities for living. DesJardings' (1993) three quality of life obligations to future generations are: development of alternative energy sources, conservation of energy resources, and a reasonable chance of happiness. Economic concerns relating to quality of work and increasing standards of living should be added to this list, in addition to other variables that are found important by the world's diversity of cultures.

Lastly, in an eclectic approach, Bell (1993) believes that humility and the cause of humanity create obligations to future generations. In his own words, "Humble ignorance ought to lead present generations to act with prudence toward the well-being of future generations." In addition, he identifies "a prima facie obligation of present generations to ensure that important business is not left unfinished."

\subsection{DECISION THEORETIC VIEWS}

Principles of obligations to future generations and other life-forms with respect to sustainability need, in the view of many, to be made more explicit for decision making and policy setting purposes. To economists and decision theorists, the question is what can and cannot be traded off (Farrell 1996). Norton (1992) discusses "a two-tiered system of values in which some values are interchangeable and some are non-negotiable. This approach envisions biodiversity as a . non-negotiable obligation to future generations to protect the diversity and complexity of self-organizing systems." Bishop (1993) seconds this view: "The minimum standard paradigm places biodiversity beyond the reach of routine tradeoffs. Biodiversity could only be sacrificed in the face of intolerable costs. . . Applying efficiency criteria to biodiversity/preservation issues can be problematic." Toman (1994) uses the 'safe minimum standard' concept in this regard. Economists like Solow (1993) are coming to believe that it is not wise to trade-off natural capital and items such as non-renewable resources, stock of plant and equipment, technological 
knowledge, and education which are a "kernel of sustainability" that must be maintained into the indefinite future.

In addition, applying standard methods found in economics and decision analysis also becomes problematic with respect to sustainability. Howarth and Monahan (1993) argue that "gross uncertainties associated with climate change and the distribution of impacts between present and future generations constrain the usefulness of cost-benefit criteria in evaluating climate policy." Sagoff (1994) argues that preferences, and therefore preference theory that underlie much economic theory, cannot be used for environmental decision making as opposed to decisions among well specified choices. Other methods are being explored. One such approach is possible worlds analysis, which structures the decision-making problem around the analysis of risks posed to future generations in many potential states of the world over time (Tonn 1994). Possible worlds analysis emphasizes the prevention of possible worlds characterized by unacceptable risks to the sustainability of environmental, social, and economic systems.

Statistics Canada's view of sustainability draws from many of the themes presented immediately above (Rapport and Friend 1979). Specifically, three decision criteria are set out:

- stewardship: the need to protect and conserve environmental assets for future generations;

- environmental quality: the need to maintain and enhance the quality of the ambient environment for quality of life objectives; and

- irreversibility: the need to make explicit the closing of potential options by human-initiated permanent restructuring of the environment, i.e., ecosystem destruction.

Statistics Canada proposes yet another decision theoretic concept, that of irreversibility. It is an important concept within the decision theoretic paradigm toward sustainability. Another important concept is the precautionary principle. For example, Stoett (1994) argues, lest decision theorists 
become too enamored with collecting all the facts before making a decision, "... The precautionary approach shall be widely applied by States according to their capabilities. Where there are threats of serious or irreversible damage, lack of full scientific certainty shall not be used as a reason for postponing cost-effective measures to prevent environmental degradation."

\subsection{PUBLIC PARTICIPATION}

Throughout the previous paragraphs, the importance of democracy and freedom have been alluded to (e.g., Robinson 1989, Hodge 1997). Many believe that sustainability can only be achieved through the concerted effort of large numbers of people acting through their strong, collaborative democratic processes (Kinsley 1995). As an example of this viewpoint, Soerensen (1995) states that public participation to achieve sustainability entails: “. . . shaping a range of collaborating future societies through a conscious democratic process, instead of having more or less arbitrary events and interests groups determining the path of change."

Chiras (1995) combines many of the ideas mentioned above into four principles of sustainable development: "ecological (biophysical limits, carrying capacity); ethical (ecological and social justice, cooperation with nature); economic (equity, market limitations, growth, increase quality of life); [and] political (freedom, participation in democracy)," where especially the fourth principle stresses strong political systems. Tonn and White (1996) present ten principles for a sustainable society: wisdom, tolerance, human rights, participation, spirituality, collaboration, achievement, sustainable communities, decision making under uncertainty, and learning. These principles expand the notion of democracy into other realms.

Grove-White (1997) states that sustainability demands movement towards: “. . . more frugal energy and waste systems and towards ever tighter pollution controls (in relation to issues ranging from climate change to local asthma) ... more public transport and more environmentally sensitive agriculture and conservation of land." Additionally, with respect to public participation, the 
following points are made: "(1) first, in thinking about the future it is vital to keep in mind a realistic sense of the increasingly limited capacities of our political institutions for effective positive policy interventions (decreasing public trust about everything - politics, science, professions, makes for turbulent policy arena). (2) increasingly global patterns of economic development and competition (3) new patterns of anxiety and exposure to risk (4) response of government withdrawal, downsizing, privatization, markets. . . People and people's interaction with one another may now be the key." Reed (1994) also worries about "Limitations of local decision making: broad representation of stakeholders; opportunity for strategic focus and information exchange; shared decision making and implementation strategy; long-term implementation strategy."

Brown (1997) argues that new forms of organizations are needed to achieve sustainable community development. At the very least, Barlow (1997) asserts, “. . . economic pressures resulting from global competition, and societal pressures associated with the need for sustainable development, are providing a basis for new responsibilities and new expectations with regard to metropolitan governance ..." These responsibilities may require new alternative approaches to planning based on concepts found within such small scale experiments as co-housing and eco-villages (Hygeia 1995). Additionally, Dovers (1996) states that institutions may need to be rethought to ensure that effective decisions can be made in the face of uncertainty, and that managing uncertainty and ignorance are central for success. Gibbons (1992) offers that approaching public policy as a process, not an event, helps to make decision making and institutions adaptive, thereby making uncertainty less important than it otherwise might be. Sessions (1993) states that process requires capacity building of institutions to achieve that task. Agenda 21 places much emphasis on capacity building (Sitarz 1993).

Many believe that sustainability comes down to individual responsibility. For example, Burgess and Harrison (1997) state that "Exhorting people to change through dramatic advertizing, scare stories, guilt trips or appeals to their 'better nature' [is] no longer seen as an effective strategy. ... It [is] agreed that public, private, and voluntary sector organizations must begin to change their 
own practices to demonstrate to others that it is possible to live and work in more sustainable ways." Doob (1995), a psychologist, argues that people need to have a personality for sustainability, to invest in the future, and to value others but that people who possess these characteristics nevertheless may have difficulty in being "sustainable" due to limits of time and knowledge. For those people so inclined, Hollender (1995) presents one hundred sixteen ways that people can make the world a better place. Actions range from saving energy and water in and around your home to socially responsible banking and investing. The fact that there are many such books on the market indicates a reasonable level of interest by individuals in sustainability.

\subsection{PRACTITIONERS VIEWS}

Sustainability is fast becoming a rallying point for communities across the country, as seen by numerous efforts to build indicators for sustainable communities (e.g., see Atkinsson 1996). Lyday (1998) elicited from a small number of communities their definitions of sustainability. Summarized in Table 1 are definitions given by people in seven communities. Overall, the definitions are fairly consistent with many of the notions found in the literature; Metro Dade, Florida, has even adopted verbatim the Brundtland Commission definition. Included in the definitions are concerns about the environment, the need for self-sufficiency, and public participation. Where the definitions are inconsistent with the literature is at the global level. Notions of entropy, reducing extraction of substances from the lithosphere, and population control are absent from these definitions. This observation will be revisited in the following sections. 
Table 1. Local notions of sustainability (Lyday 1998).

\begin{tabular}{|c|c|}
\hline Place & Notion of Sustainability \\
\hline $\begin{array}{l}\text { Russell County, } \\
\text { Virginia }\end{array}$ & $\begin{array}{l}\text { It's what lasts and enable the people to last. Whatever can maintain } \\
\text { and enhance current status of community. }\end{array}$ \\
\hline $\begin{array}{l}\text { Asheville, North } \\
\text { Carolina }\end{array}$ & $\begin{array}{l}\text { A total process that combines community and commercial and } \\
\text { environment and government. Total community looks at how we } \\
\text { work with each other for a healthy community. Creating synergy } \\
\text { between bissiness and quality of life. }\end{array}$ \\
\hline Cobbscook, Maine & $\begin{array}{l}\text { Balances attention to economy, the environment, community and } \\
\text { education. This is the definition that the community developed based } \\
\text { on what it identified as its values. }\end{array}$ \\
\hline Metro Dade, Florida & $\begin{array}{l}\text { Managing resources to meet today's needs without compromising the } \\
\text { ability of filture generations to do so. (Brundtland) }\end{array}$ \\
\hline $\begin{array}{l}\text { Swain County, North } \\
\text { Carolina }\end{array}$ & $\begin{array}{l}\text { It's a community that takes advantage of its resources and can } \\
\text { support itself. }\end{array}$ \\
\hline Minneapolis, Minnesota & $\begin{array}{l}\text { Self-sufficiency in enterprises. Environmental sustainability also } \\
\text { important - improving it or at least making it no worse. Also } \\
\text { concerned about community involvement and participation. }\end{array}$ \\
\hline $\begin{array}{l}\text { Presidio National Park, } \\
\text { San Francisco, } \\
\text { California }\end{array}$ & $\begin{array}{l}\text { Sustainable community is one that values and measures its resources } \\
\text { including ecological, economic and human resources in a way that } \\
\text { improves quality of life now and into the future. }\end{array}$ \\
\hline
\end{tabular}

\subsection{SUMMARY}

To summarize, the concept of sustainability, taking into account all the viewpoints, is actually extraordinarily complex, maybe even confused. What may appear "clear to the heart but not the mind" (Schiller 1998) may be due to the fact that sustainability is an evolving concept. However, 
taking the material at hand and with respect to the intentions of this research, the various viewpoints implore people, in the grand sense, to behave in various manners. Following is our distillation of these exhortations:

- limit resource use - e.g., energy, water, minerals;

- reduce pollution;

- recycle;

- control population;

- protect biodiversity;

- constrain the pace of change;

- limit consumerism;

- conserve land;

- practice strong democracy;

- achieve intra- and inter-generational equity;

- meet basic human needs;

- adopt sustainable personalities; and

- implement proper decision-making heuristics, such as the precautionary principle.

This is an imposing list. Taken up in the following two sections are how it is difficult, if not impossible in some ways, first for communities to meet these goals and second for individuals to meet these goals. 


\section{THINKING GLOBALLY, ACTING LOCALLY: POTENTIAL DISCONNECTS}

The purpose of this section is to examine relationships between the list of prescriptions presented at the end of Section 2 and the abilities communities may have to translate them into effective policies and programs. This section outlines seven difficulties communities may face in this endeavor: linking global sustainability prescriptions to local goals; lack of empowerment to meet sustainability prescriptions; severe external constraints to sustainability; institutional barriers; dissonance between economic growth and sustainability goals; very long decision-making time horizons; and complex decisions that entail enormous uncertainties. The section concludes with a brief review of community sustainability efforts which supports many of the assertions made immediately below.

\subsection{GLOBAL PRESCRIPTIONS TTO LOCAL GOALS}

Global sustainability prescriptions need to be translated into community sustainability goals. This assertion has three components. The first is most straightforward: communities need to know how much. In other words, given integrated global assessments of sustainability and the environment, how much:

- land should a community conserve (e.g., for agriculture);

- renewable and non-polluting energy sources should be developed and used;

- non-renewable and polluting energy sources should be diminished;

- water should a community conserve;

- recycling of what materials should be accomplished;

- emissions of what air and water pollutants should be reduced; and

- etc. 
Currently, communities involved with sustainability efforts understand intuitively that land should be conserved, that water should be conserved, that materials should be recycled, that emissions of air and water pollutants should be reduced, etc., but in the scheme of things, in order to save the earth, what goals must their particular community meet? Is it reasonable for the community to cede 1000 acres of greenfields to subdivision and industrial development given that across the country other communities are doing the same? Should different communities have different targets? Similar questions hold for many of the other prescriptions. In most cases, communities do not have clear and definitive answers to these questions. In other words, prescriptive goals have not been developed in an integrated fashion for communities, for the majority if not for almost all of the prescriptions associated with sustainability. One can argue that these goals are needed for community sustainability indicators and efforts to be rigorous and effective across scales and among often competing local jurisdictions.

A second element of this assertion is that many of the prescriptions are not understandable or easily implemented at the community level. For example, what does the Natural Step principle, "substances extracted from the lithosphere must not systematically accumulate in the ecosphere," mean to a community? Some of the exhortations are simply difficult to understand because they address very complex social science concepts. For example, how should a community understand and achieve strong democracy? Is equity only defined via political process or it is a concept that exists independent of political outcome? What is the best way to implement precautionary principles in local decision making? How should such decisions be made?

A third element of this assertion relates to the systems aspects of global sustainability. Thinking globally, acting locally is not as easy as the catchiness of the phrase suggests. The natural tendency for communities is to look inward, to focus on local goals and values. It is hard for communities to view themselves as part of a larger system, in part, because the world beyond their jurisdictions is extraordinarily complex, and as is discussed in Sect. 3.3, mostly beyond their control. Thus, it can be quite difficult for communities to understand how their behaviors, if multiplied by thousands of other communities across the country if not the world, can have significant positive or negative 
consequences for global sustainability. Such relationships between community behavior and sustainability prescriptions need to be made clear to communities.

In summary, there exist disconnects between global sustainability prescriptions and potential community-level sustainability goals. Communities require better guidance as to how much needs to be achieved, and what exactly can be achieved within what time frames. Some assurance about what can be achieved in a reasonable amount of time with a reasonable expenditure of effort and money will be more likely to result in such achievements. Communities also need to understand beyond a superficial level their place in the integrated global sustainability reality.

\subsection{COMMUNITY EMPOWERMENT}

Communities are not empowered to achieve many global sustainability prescriptions. Let's assume that communities understand what needs to be achieved, appreciate the systems dynamics of global sustainability, and have specific and reasonable goals related to how much water needs to be conserved, etc. The questions addressed in this subsection are: what prescriptions are beyond the ability of communities to meet; and what prescriptions can communities possibly meet?

To begin, what kinds of powers do municipalities in the United States (and Western countries more generally) have and what kinds of activities do they normally pursue? According to Flyvbjerg (1998), municipalities can do planning; for streets, malls, squares, bicycle paths and highways where the municipality owns the property or right-of-way, has the right of expropriation, and controls significant sums for capital construction and operations. Municipalities have more difficulty with urban renewal because municipalities often do not own the property or lands and may lack the required money. Municipalities can enact zoning ordinances, and sometimes growth controls. They can pass ordinances that pertain to a wide range of everyday matters, from parking to solid waste disposal. They can also implement educational programs and information campaigns. 
Unfortunately, these powers are insufficient to meet several central global sustainability prescriptions.

For example, let's assume for the sake of argument that each community can be given a population target to meet, such that the aggregate of all the population targets would yield a sustainable level of people that the earth could sustain. It would be understood that the target needed to be met not by excluding people from the community but through direct regulation of human fertility. Besides the fact that such direction is unlikely to be forthcoming from the international community at any time soon, this prescription is an excellent example of what communities cannot do in the name of sustainability; they cannot control population at the level of fertility. Simply put, communities have no legal power to regulate the number of children that women can bear. Communities do operate and let operate family clinics and other related organizations within their jurisdictions, but these organizations focus on family planning issues from the perspectives of families and women, and not from the perspective of sustainability. Thus, calls to control population and to achieve populations at levels that the earth can sustain cannot be acted upon in a strong manner by communities in the United States.

Theoretically, very specific prescriptive guidelines also could be generated for consumption of energy per capita and consumption of material goods per capita. Beyond possibly being able to influence energy efficiency standards of products sold in a community, and building codes and standards, and possibly being able to influence prices of energy through regulation of local electric utilities (e.g., electricity, gasoline), communities in the United States have no legal authority to regulate the amount of energy used in its community. Similarly, for material goods, beyond instituting a strict system of rationing, which would be very unlikely in the United States in a non-war time situation, regulating consumption of material goods is also beyond community power.

Communities may have some control over the achievement of other prescriptions. For example, there are precedents in the United States for strong local controls over water consumption, 
especially in the arid western United States. Many communities run active recycling programs and stimulate recycling through various fees and penalties. Through zoning and acquisition of development rights, communities can also control the use of land to a degree, although pressures to develop greenfields are strong. The tension between private landowners, who generally want to preserve full control over the use of their land, and government, which may attempt to impose land-use restrictions in order to achieve societal goals (often goals which have common-good characteristics), is most sharp in arguments about whether or not such actions are unconstitutional 'takings' or not. Not having specific directives and not understanding systemic relationships makes it more difficult to conserve a small wetland or a small patch of virgin forest because no one really knows whether these particular resources are important in the larger scheme of things. In all of these contexts, strong controls must overcome strong resistance to the controls.

The question of how communities can meet environmental prescriptions is complex. In some areas, such as emissions from toxic waste incinerators and discharges into surface waters from point sources, communities are generally empowered to meet any such global prescriptions. In some other areas, such as biodiversity, comrnunities may not be able to act alone to achieve such goals. With respect to preserving the habitats of higher order mammals, for instance, there needs to be regional, national and maybe international cooperation to achieve biodiversity goals. Some prescriptions, such as meeting specific per capita emission targets for greenhouse gases, non-point urban run-off, and indoor air pollutants are simply difficult from a practical standpoint regardless of the regulatory powers a community may possess.

\subsection{EXTERNAL INFLUENCES ON COMMUNITIES}

Strong external socioeconomic influences can constrain community sustainability efforts. As indicated above, there are many global environmental prescriptions that U.S. communities are not empowered to meet. In addition, there are many external influences that act upon communities that limit what they can do. In fact, for many communities, as noted in Table 1 in Section 2 , 
sustainability is as closely associated with economic and social survival in the face of strong external influences as it is with environmental protection.

This list of external influences that impinge upon communities and render their borders extremely porous is rather long. By and large, U.S. communities cannot control these external influences:

- immigration and emigration of population. Freedom of movement is a protected right in the United States. Indeed, the United States is a country of movers, as about one in four households moves each year. Communities cannot control this movement, which can have devastating consequences for community social stability needed for achieving long-term sustainability goals;

- flows of goods, materials, and services. Communities and states are constitutionally prohibited from controlling interstate commerce. This makes it difficult to control what goods and materials get imported into the community that then have to be disposed of;

- flow of money. Related to the point above, communities cannot control the flow of money across their borders. The more money flowing out of a community, to pay for energy and food for example, the more the community needs an export base to attract money into the community to pay for imports. Although this problem is at the heart of economic development discussions in communities across the country, communities actually have very little influence over this matter because it is largely in the hands of the private sector. To combat this problem, several communities across the United States (e.g., Ithaca, New York) are experimenting with "local currencies;"

- taxes and regulation. Communities have little influence on taxes and other regulations set by states and the federal government. One result is unfunded mandates that can place unexpected and significant burdens on communities;

- pollution. Communities have little control over pollution generated by other communities, especially in cases where federal law is weak or non-existent. Thus, the best efforts by the best communities to meet sustainability prescriptions may be thwarted by their neighbors, whom they may be powerless to influence; 
- information. National publications, mail, radio, telephone, television, and now the Internet render community borders invisible with respect to information. In general, free flow of information brings positive benefits. However, with respect to communities and sustainability, extensive communications beyond communities' borders (e.g., to associate with virtual communities) may weaken the ability of spatially-defined communities to carry out strong and energetic sustainability programs;

- technology. Technological progress and change are washing over the socioeconomic landscape. Some technologies may be beneficial with respect to meeting sustainability goals (e.g., more energy efficient appliances, cleaner cars). Some technologies may act against sustainability goals (e.g., low miles per gallon sport utility vehicles).

Communities have no influence over what technologies are developed by companies across the world and introduced into local consumer markets.

- corporate influences. It is now common for the economic fate of communities to be decided by corporate executives in other states if not other countries. These decisions can bring new facilities, jobs, and tax revenues to communities or just the opposite. Communities can offer economic incentives to companies to locate and stay, but it is often the case that the incentives cost the community more than is gained, and it is often not clear how important such considerations are in corporate decision making; and

- infrastructure networks. Communities are laced with regional, national, and even international infrastructure networks, from aviation networks to interstate highways to electricity transmission lines to fiber optic cables. Communities cannot disconnect themselves from these networks and often have to go along with larger forces that influence infrastructure decisions.

These forces in the aggregate can often place sustainability concerns, as expressed in Section 2, far down the list of priorities and make some prescriptions impossible to meet. For example, these forces make it extraordinarily difficult for communities to control the pace of change, at least with respect to its socioeconomic context. Some sustainability programs may be seen as a luxury 
(indeed some communities now no longer feel they can afford the cost of municipal recycling programs). In the press of trying to maintain jobs and a tax base, decision making principles sensitive to sustainability goals (such as strong democracy, inter-generational equity and intra-generational equity, too) may simply be ignored.

Even more fundamentally, communities have little influence over the variables in the famous IPAT formula, where environmental Impact $=$ Population $\mathrm{X}$ Affluence $\mathrm{X}$ technology (Ehrlich and Holdren 1971; Olson 1994). From the previous subsection, it was argued that communities do not have the ability to control population nor material consumption associated with affluence. In this subsection, it is argued that communities do not have the ability to influence technology and associated factors such as flows of goods, materials, services, and money. Thus, one can conclude that the ability of communities to meet many important global sustainability prescriptions on their own is fundamentally circumscribed.

\subsection{EVERYDAY CONSTRAINTS ON COMMUNITLES}

Many everyday factors constrain community sustainability efforts. These factors are essentially institutional in nature and impact a community's ability to formulate and carry-out long-term sustainability efforts. Tonn and Peretz (1998) summarize many institutional problems that can have negative affects upon environmental decision making processes. These include: (1) turnover among decision process participants; (2) difficulties in building and maintaining expertise in government; (3) lack of credibility of participants in environmental decision-making processes; (4) difficult relationships between government and the public; (5) difficult relationships between state/regional/federal governments; and (6) lack of institutional support for decision makers. In combination, these factors adversely affect the implementation of sound environmental decisionmaking practices, the ability to focus upon the right environmental problems to solve, the ability to identify the best solutions to the problems, and the ability to make timely decisions. It is argued 
that these same problems afflict sustainability decision making, which subsumes environmental decision making into an even more ccmplex and challenging decision-making context.

Other factors also constrain sustainability efforts. Communities often lack the financial resources and staff to conduct analyses and implement programs. Tonn and Peretz (1997) found that time pressures also significantly hinder environmental decision making. On one hand, many key staff have too much to do, and little time to get things accomplished. On the other hand, expectations of how quickly government should operate are increasing, probably due to the quickening pace experienced in the business world. These factors can act to reduce the quality of community sustainability efforts.

\subsection{ECONOMIC DEVELOPMENT VALUES AND GOALS}

Conceptual definitions of sustainability that emphasize minimalism and conservation conflict with typical community economic development values and goals. In psychological theory, as is noted in Section 4, many occasions arise where people are confronted with disconnects between various strongly held beliefs and between those beliefs and fundamental psychological motivations, which are achievement-oriented in nature. These conflicts have the potential for causing unsettling cognitive dissonance, which can only be overcome by changing one's values or suppressing the reality behind the conflict.

Communities are susceptible to these same problems. With respect to sustainability, a disconnect arises between prescriptions related to minimizing resource use and conserving lands, waters, etc. and centuries old beliefs in progress, economic growth, and increasing economic consumption as a most important factor in improving the quality of life (Minnesota Planning Environmental Quality Board 1998). Sustainability prescriptions are often framed within a context that conflicts with local concerns for better jobs and higher tax bases (within a context of survivability discussed in Sect. 3.3). The latter concepts can be seen to more closely match achievement-oriented psychological 
motivations because they are framed as positive goals whereas sustainability prescriptions are typically set in negative terms - don't do this, don't exceed these thresholds.

Dovers and Handmer (1993) list many additional questions with respect to sustainability. For example, is technology the cause or the cure of the problems? How can intra- and intergenerational equities be simultaneously balanced? How can economic growth be promoted in the face of ecological limits? How can individualism versus the collective interest be reconciled, especially when participatory democracy seems to weigh against purposeful action? What does resilience in the face of change really mean (resistance to change, marginal change, adaptation)? Is optimization, in the sense that it is the goal of rational policy making to move toward the best possible state-of-the-world, anti-sustainability, due to the loss of resiliency that is characteristic of systems optimized for particular conditions that will not hold into the future?

A challenge, then, is to frame sustainability prescriptions in a more positive framework. The reframing also needs to help resolve these and other sources of potential cognitive dissonance.

\subsection{TIME FRAMES}

The time frames implied within frameworks of sustainability are, for the most part, beyond normal political time frames. The most straightforward view with respect to this assertion is that sustainability issues extend far beyond the normal political cycles, which in the United States are generally two, four, and six years in duration. In order to justify re-election, politicians typically support programs and activities that have tangible benefits within their particular election cycles. Sustainability efforts may not provide tangible benefits for many years, and in some instances, may only result in the absence of negative consequences, which, of course, are more difficult to notice and assign credit for. 
Time also plays a part in many other aspects of sustainability at the community level. As mentioned above, tangible benefits resulting from today's sustainability decisions may not be felt for many years. To assess the soundness of todiay's decisions, long-term evaluations need to be implemented. Today's decisions need to be fully documented so that those in the future will understand the context and reasons behind the decisions. Careful documentation is needed because those involved in today's decisions may not be involved in the evaluations many years hence.

Given the current problem with turnover in government, as discussed in Sect. 3.4, the probability is high that original actors will not be around in the future to provide their personal memories about past decisions. Thus, institutional mernory needs to be managed in such manner to allow passing down memories over time to foster these important assessments.

Sustainability decision making at the community level is not only characterized by major decisions at critical points in time but also by an accumulation of less prominent decisions and implementations over very long periods of time. Continuity is needed to derive the most benefits from decisions over time that may build upon each other. Continuity is also needed to implement programs in consistent, systematic, and interrelated manners over a large number of years.

Flyvbjerg (1998) found that discontinuity in decision making and implementation severely damaged the integrated implementation of comprehensive traffic, development, and environmental quality plans in a leading city in Denmark. Long time frames can work against continuity if institutional memory and intentions are not passed along. These efforts can also become an advantage for communities in terms of economic and technical abilities to quantify and measure other types of successes (e.g., business, social programs, education).

\subsection{DIFFICULT DECISIONS}

Sustainability decision making is extraordinarily difficult for communities. Even without the difficulties expressed in the first six subsections of Sect. 3.0, sustainability decision making is an considerable challenge for communities, if indeed they attempt to address the prescriptions distilled 
in Sect. 2.0. The most difficult decision-making aspect is dealing with the uncertainties inherent in the future. As noted in Sect. 3.3, the reality within which communities exist can be highly turbulent. Many factors work to cause uncertainty in basic concerns related to population, economic health, cultural health, and environmental quality. On top of that uncertainty, global sustainability prescriptions direct communities to conserve land and water, protect biodiversity, etc. for the benefit of many generations to come.

Additional sustainability prescriptions indicate to communities that sustainability decisions need to be equitable, meet basic human needs for today's and tomorrow's populations, and follow suggested decision heuristics, such as the precautionary principle. As discussed in Sect. 4.7, individuals on their own can have great difficulty internalizing the decision issues inherent in sustainability. At a community level, the requirement for strong democracy means that many people who are probably having great difficulties understanding sustainability as it relates to their own lives are brought together to make sense of it all. This is all done in an atmosphere where global sustainability prescriptions bear down on communities that lack the powers and, in some instances, the value systems to adequately handle the task.

\subsection{OBSERVATIONS}

The above assertions about barriers communities face with respect to meeting global sustainability prescriptions, what communities might be able to do with difficulty, and where they might focus their efforts are generally supported by material reviewed about current sustainability efforts in several of the most active communities in the United States.

The sustainability indicators and activities recounted to Lyday (1998) by numerous communities across the United States cover a wide range. Included are such elements as community gardens, landscape ordinances, wetlands development guidelines, protecting the Everglades, new urbanism (i.e., mixed use developments suited for walking, front porches), waste minimization, cleaning up 
trash and junked cars, and preserving farmland. Only some of these activities are related to global sustainability prescriptions (e.g., waste minimization, preserving farmland). The list, as expected, does not contain activities that were asserted above to be beyond community powers. The activities, while motivated by concepts of sustainability discussed in Sect. 2, do not seem to be set within a larger systems context of sustainability nor guided by any national or international targets. Most community-based sustainability indicators and activities share these general characteristics (Zachary 1995).

For example, the City of Santa Monica, California has published an initial list of twenty-one sustainability indicators (Santa Monica 1998). The indicators stress reductions of solid waste to be landfilled, water usage citywide, electricity and natural gas usage, use of hazardous materials, and wastewater flows, and increases in mass transit ridership, percent of city fleet vehicles using reduced emissions fuels, and public open spaces. A high majority of the indicators relate to activities directly under control of the city. Other than indicators related to mass transit and reduced overall electricity and natural gas usage, no indicators aim at changing individual behavior. As expected, there are no indicators clealing with overall fertility, per capita resource consumption, or per capita energy consumption. There are also no social indicators, such as increasing volunteerism, which is important to sustainability prescriptions related to democracy.

Most of the ninety-two indicators that compose the Oregon Benchmarks (1998) pertain to human-centered quality of life issues (e.g., crime, education, parks, health). A few focus on conserving land, especially agricultural land. The environmental indicators address meeting federal or state regulations, with reductions in carbon emissions an important exception. The Oregon approach is laudable from a social policy perspective, but again, and as expected, it falls short of comprehensively meeting the entire list of global sustainability prescriptions.

The ideas put forth by the Minnesota Planning Environmental Quality Board (1998), however, are generally consistent with the prescriptions noted in Section 2. Indeed, The Natural Step principles have been adopted and the plan emphasizes maintaining use of renewable resources at a sustainable 
rate, limiting emissions of toxic materials into the environment, meeting the needs of future generations, conserving land, and protecting biodiversity. The plan contains specific actions needed to achieve these goals. The plan is too new for there to be indications whether progress has been made in these areas. The enhanced comprehensiveness of this plan may be due to its being promulgated at a state level, rather than at a community level, which again indicates the importance of scale issues in sustainability.

In conclusion, the point of this section is not to argue that communities need the power to regulate human fertility, energy use per capita, and consumerism. The purpose of this section is simply to point out serious potential disconnects between global goals of sustainability and what can be accomplished unilaterally by communities. Devolution of sustainability responsibilities to communities may not result in the achievement of as many sustainability goals as one might hope. National and international governments still have an important role to play in preparing guidelines for communities and in tackling the most difficult aspects of the IPAT equation. Much like Miller's (1978) general theory of living systems, communities exist within a range of organization types and should have responsibilities commensurate with their capabilities. 


\section{CONSTRAINTS ON INDIVWUALS' SUSTAINABMITY EFFORTS}

In this section, we turn to an analysis of constraints on individuals that influence their ability to act in a manner consistent with frameworks of sustainability. For this analysis, we assume that human behavior is guided principally by (a) what people can do given constraints present in their everyday environment or contexts within which they are behaving, and (b) what people are inclined or motivated to do given their knowledge, beliefs, attitudes and values. Constraints on behavior come about from two sources: environmental or contextual factors that render the behavior (more) difficult or impossible to perform (e.g., insufficient time, lack of resources), and psychological factors that inhibit the motivation for the behavior.

Our interest in this section is on exploring the implications of the global sustainability prescriptions distilled in Section 2, which are mostly defined at a social level or higher, for individual behavior. Thus, our concern is with identifying barriers at the individual level to meeting the prescriptions that have been conceptualized at a social level.

We do not intend to submit various theories to this test, nor will we choose a particular theory of sustainability as an exemplar of all theories to serve as a proxy or standard by which we can gauge the potential for its implementation. Rather, we will regard theories of sustainability as a class of social theories and theoretical policies intended to conceptualize the impacts of humans on the natural environment. This is set withir a value framework that emphasizes the need to insure a continuation of natural resource availability and pollution minimization for future human generations through some combination of measures or steps, including natural resource conservation, reduced consumption, population control, and protection of environmental quality and diversity. 


\subsection{GLOBAL PRESCRIPTIONS TO INDIVIDUAL GOALS}

Global sustainability prescriptions are not well expressed in terms relevant to individual behavioral goals. Theories of sustainability are rooted in a systems-based view of humans and their environment. The prescriptions offered by such theories for establishing and maintaining a sustainable future are represented or expressed in terms of macro-level factors, such as global energy utilization, population fertility, or air pollution levels. While theories of sustainability are generally clear about the direction that such variables should take to minimize environmental impact (e.g., less energy utilization is better), the specific contribution that an individual can or should make is much less clear. However, individual behavior is driven by personal goals and objectives. Thus, for sustainability prescriptions to have behaviorally-relevant meaning to individuals, their components need to be expressed in terms that individuals can monitor and control. For example, per capita energy reduction indicators are more compatible with individual actions to support sustainability than are global indicators of energy utilization.

A second difficulty with sustainability prescriptions is that they often involve tightly integrated concepts that are heavily science laden. Systems-based thinking is not a natural psychological process and most individuals are not sufficiently science-literate to translate complex systemsbased models into a prescription for everyday life. Moreover, the science associated with sustainability theories often includes bands of uncertainty that tend to cloud the exact meaning or value of individual behavior. Given the lack of exactitude in such models, individuals could conclude that their personal behavior is of little or no consequence. However, if all individuals reach the same conclusion, then their collective social behavior will be away from sustainability.

One component of sustainability theories that gives individuals particular difficulty is the exponential nature of environmental change. That is, most sustainability theories (in one way or another) posit that environmental decline or impact is not linear with time, but rather accelerates with increasing environmental damage. Population models, for example, are exponentially increasing. Non-scientists have much difficulty with exponential processes and generally 
underestimate the rate with which an exponential function increases over time (e.g., Wagenaar and Timmers 1979; Brehmer 1990). Thus, individuals attempting to translate prescriptions of sustainability into terms that are meaningful for everyday life are very likely to have difficulty translating their components into behaviorally-relevant terms, either because the scale of the variables is not appropriate, or because the interrelationships within the models are too challenging for their intuitive judgment.

\subsection{INDIVIDUAL EMPOWERMENT}

Individuals are not empowered to acheve many global sustainability prescriptions. For individuals to act successfully in achieving sustainability goals, they must have the power to do so. However, in some instances, individuals are empowered to act. For example, people can reduce their energy consumption by simply using less electricity or reducing their reliance on motor vehicles (such as by using public transportation). However, in many instances, individuals can do little to meet sustainability prescriptions. For example, many theories of sustainability propose changes in land use. While individuals in a democratic society can act to influence land use laws, at the individual level there is little that one person can do directly to effect such changes. A second example is species or ecosystem preservation, particularly where the species or ecosystem is on another continent. In these cases, the only way' that an individual can act is by proxy through, for example, membership in organizations like The Nature Conservancy or World Wildlife Fund or through informally coordinated efforts, such broycotts of generic products or products produced by specific companies. Thus, some sustainability goals such as those related to many aspects of biodiversity are goals that cover large scales and to achieve them at an individual level will require a great deal of refinement and translation into terms that are compatible with the empowerment that individuals do have. 


\subsection{EXTERNAL INFLUENCES ON INDIVIDUALS}

Strong external socioeconomic influences constrain individual sustainability efforts. People live their individual lives within a context that includes both social relationships and constraints, as well as economic realities. Fundamental needs, such as food, clothing and shelter must be met. Social relationships, such as family life, must be maintained. Modern life in Western societies is enormously demanding in terms of time and intellectual resources. For example, many families today in the United States require two incomes to maintain even a middle class standard of living. The precepts of good parenting dictate that a significant portion of family time be spent interacting with children and providing them with social and cultural opportunities. Tonn and Petrich (1997), in a review of constraints on environmental citizenship, found that in contemporary America the vast majority of individuals have insufficient time, money or resources available to participate in environmental democracy in the ways that would be required to effectively manage our environmental problems.

These same conclusions can be drawn for sustainability efforts as well. Given the prescriptions for sustainability available today, the typical individual would need to spend a great deal of time and effort to internalize those prescriptions in terms that are both personally meaningful and behaviorally implementable. It is questionable whether the "budget" of time and resources is sufficiently large to accomplish that.

For the most part, people's lives are dominated by worries and concerns that are pertinent to maintaining central life goals, such as career and family (MacGregor 1991). While sustainability issues are important in the abstract, they typically fail to capture a central position in what people generally regard as the important things to do on a daily basis. Though some part of this difficulty is attributable to the way that prescriptions of sustainability are framed, it is also the case that the psychological and socioeconomic resources available to develop a personal "sustainable" life are not available. 


\subsection{INDIVIDUAL VALUES AND GOALS}

Conceptual definitions of sustainability that emphasize minimalism and conservation conflict with typical individual values and goals. Definitions of sustainability emphasize minimalism and conservation, while individual patterns of consumptive behavior are driven by appetitive needs and wants. Many of these basic needs and wants are satisfied (either directly or indirectly) through personal economic behavior. However, sustainability, if fully implemented as a social policy, has significant implications for the financial lives (and futures) of individuals. Underlying the negative impacts of human activities on the earth's natural environment is the pattern of economic growth and development that has characterized our modern world, particularly in this past century. Virtually every indicator of environmental pollution or degradation is in some way reflective of a world economic order that places comparatively high values on current consumption over preservation for the future. Indeed, the concept of sustainable development embodies the principle of economic development, but in a way that allows its continuation over time. Thus, sustainability is not a "no-growth" social policy, but: rather a growth policy consistent with the renewability of the earth's resources.

Most individuals depend on economic growth to secure both their current financial position as well as future asset or wealth positions for retirement and estate planning. From this perspective, the question is one of how much economic growth is growth enough? Some answers to this question come from examining American's perceptions and expectations of economic growth. A recent survey of seven hundred fifty mutual fund investors conducted by Montgomery Asset Management asked what level of annual returns they expected on their mutual fund investments over the next year and the next ten years (New York Times 1997). The survey, conducted over each of the four quarters of 1997 during a very active bull market, revealed that growth expectations for personally-held mutual funds ranged on average from $22 \%$ to $34 \%$ on an annual basis over the next ten years! So astoundingly high are these expectations that one could reasonably question whether respondents understood the questions they were asked. However, corroboration of these results come from a more recent study of six hundred individual investors who responded to a 
telephone survey about their personal investment decision making (Slovic, MacGregor, and Dreman 1998). All of the respondents were active investors who made portfolio decisions on a regular basis and who invested in a combination of equity (e.g., stocks) and debt assets (e.g., bonds). Average annualized expected growth in the value of personal portfolios over a ten year period was $16.5 \%$, unadjusted for inflation. Even when asked to adjust for inflation, respondents' growth expectations were reduced only by about $2 \%$ to $14.8 \%$. Given that the historical rate of return in the domestic stock market (as measured by indices such as the S\&P 500) has been approximately $10 \%$ over its 60 -plus year history, these expected future returns seem both incredibly optimistic and at the same time revealing of how strongly individuals' outlooks about the future depend on levels of economic growth that are both high and unsupported by past rates of return.

These financial expectations, which one would expect to be mostly met through the conventional economic paradigm of increasing the production and consumption of consumer goods and services, place an enormous burden upon sustainability initiatives. Many companies, such as Monsanto, are adopting sustainability practices and new, greener technologies are being produced every day. Whether or not natural capitalism and technological progress can match demands for financial results is a very important consideration in the sustainability equation.

However, the important point of this analysis is that individual financial goals and objectives widely held by Americans today (and likely those of other industrialized nations as well) are predicated on personal expectations of economic growth that are inconsistent with sustainability. Are there other mechanisms that people are or could be using to help secure their financial future and that might be more consistent with the concept of sustainability? Are people using those mechanisms?

In principle, some classes of investments could provide opportunities for future growth and return, but with less impact on the earth's resources. Though all forms of investment are predicated on an expected positive return, the actual level of that return could either be consistent with sustainability, or be achieved in a way that imposes either a minimal or renewable environmental 
impact. The "socially responsible investing" movement is reflective of this latter idea; conceptually, the socially responsible investor seeks investment opportunities that have an attractive rate of return but that also avoid (at least to some degree) negative effects on the environment. Very often, these investments come in the form of mutual funds that invest their money (by buying shares) in companies whose management practices are consistent with a fund philosophy. Investors in such funds often trade off higher returns for the benefit of knowing that their investments are consistent with broader social policies or principles that they personally value.

There are, however, a number of problems with this approach to achieving sustainability goals, not the least of which is the relative unpopularity of making such trade-offs. As of this writing, there were over eight thousand mutual funds currently traded in the United States, and a large part of this market is open to investors in other countries. A cursory review of these funds using the Morningstar Principia database reveals that less than three percent of mutual funds are marketed as "socially responsible" or "green" funds. However, a larger problem is that a fund philosophy does not guarantee that some target level of sustainability is inherent in its actual investment behavior. Most investors who buy mutual funds have only a vague idea at best of the actual companies that are contained in a particular fund. Though mutual fund managers are generally expected to manage their respective funds with a consistent style, the assessment of style consistency in the financial industry is based on the economic size of the companies contained in the fund (e.g., small cap, mid cap) rather than on a general philosophy about choosing companies that have a certain image or character. Thus, mutual fund investors who choose to purchase mutual funds or stocks in companies that tout a socially responsible philosophy may overestimate the degree to which their investment behavior and its resulting economic growth actually achieves an offset to the environmental degradation accompanying that growth.

What about other investment vehicles, such as debt assets or bonds? Some types of debt assets may be more likely to be associated with sustainability principles, particularly government-sponsored debt, such as municipal bonds used to fund infrastructure improvements to waste water plants. Are such investment vehicles widely used and to what degree? Some evidence 
on these points comes from the Survey of Consumer Finances sponsored by the Federal Reserve Board and the Department of the Treasury. Among other variables relevant to assessing economic variables, the survey collects information on family income and investment/savings practices. Recent summaries of results from multiple survey years show that the overall rate of families who "save" declined from 57\% to 52\% between 1992 and 1995 (Kennickell, Starr-McCluer, and Sunden 1997). As part of the distribution of financial assets of all families surveyed, $31.2 \%$ of assets were in stocks and mutual funds. However, only $6.9 \%$ were in bonds of all types (e.g., municipal bonds, corporate bonds) and only $1.4 \%$ were in savings bonds. Thus, the Survey of Consumer Finances serves to substantiate a widely perceived general trend for American families to be highly invested in equity assets that have high expected rates of return, but relatively little investment in other asset classes. Particularly noteworthy is the low level of investment in public debt instruments.

In summary, financial matters are of central concern to the lives of individuals and their families. For most Americans (and as well for most citizens of other nations) preparation for future retirement and other financial needs typically entails investment in assets that respond positively to economic growth, thereby yielding an increase in wealth. However, individual behaviors that are consistent with the general principles of sustainability are potentially in conflict with personal financial goals. Though many individuals identify themselves as sensitive to environmental issues and express agreement with the tenets of sustainability, their personal financial expectations over the long term are likely a more powerful determinant of their economic behavior. In this conflict of principles, individual behavior is typically more driven by the desire to achieve financial goals that are realizable within a personally defined time frame (e.g., retirement) than by goals and objectives that emphasize limited economic growth and potentially lead to personal sacrifice and no assurance of attaining sustainability. 


\subsection{PERSONAL ATTITUDES}

Personal attitudes about the environment and about the future of humanity are often inconsistent. For individuals to act in some consistent way with theories of sustainability, they must possess the necessary attitudinal predispositions. That is, they must have a generally consistent and positive inclination toward sustainability and the actions required to bring about its goals. The fact that sustainability has drawn so much attention in recent years, as have environmental problems and issues in general, is some indication that broad public attitudes are at least partially in line and are harmonious with taking appropriate artions. A detailed substantiation of these views is provided by various public polls conducted and rejorted through the 1990's that have generally indicated a very high level of endorsement of statements reflective of a positive environmental attitude. For example, in a 1990 survey of public views on environmental protection (Dunlap 1991a, 1991b), $74 \%$ of the respondents agreed with the view that "protecting the environment is so important that the requirements and standards cannot be too high, and continuing environmental improvements must be made regardless of cost." Furthermore, $62 \%$ of the respondents in the same survey indicated that "there is too little government regulation in the area of environmental protection." In a 1989 Harris poll, $97 \%$ of respondents felt that "this country should be doing more to protect the environment and curb pollution" (Harris 1989). Over the past decade, this trend of strong positive endorsement of the need for environmental protection has continued. Thus, it is reasonable to conclude at this point in time that the majority of the American public holds attitudes that are moderately or strongly in favor of environmental protection and restoration, at least in the abstract, and are positively disposed toward hypothetical social policies that would curb economic expansion and development in favor of environmental protection.

However, very often these general, ard sometimes strong, views regarding the environment fail to translate into specific behaviors that are in keeping with the principles of sustainability. Had that been the case over the past one or two decades, we would likely have seen greater conservation and environmental protection measures than we do today. What factors are potentially at work to inhibit what often appears to be a powerful environmental protectionist consciousness, as evident 
from survey studies, from manifesting itself in individual behaviors directly impacting sustainability?

One possible explanation lies in examining how people manage complex issues in their lives, such as those involving technology and the environment. Research in cognitive psychology has shown that for many important information processing tasks that people face in life, they employ various strategies that ease their mental burden through simplification (Kahneman, Slovic and Tversky 1982). A powerful simplifying strategy that plays an important role in environmental perception comes from work on worldviews. Worldviews are general attitudes or beliefs that predispose people toward different outlooks and that have an influence on their judgments about complex issues, such as social policy and organization (Buss, Craik, and Dake 1986; Cotgrove 1982; Dake 1991; Jasper 1990). Dake (1991) has conceptualized worldviews as "orienting dispositions" because of their role in guiding people's responses in complex situations. Though research on worldviews has been motivated in part by the desire to identify dimensions along which individuals can be differentiated in terms of their viewpoints regarding technology in society, a single individual can hold multiple worldviews depending on situation and social circumstance. Some of the worldviews identified to date are listed below, along with representative attitude statements:

- Fatalist (e.g., "I feel I have very little control over the big things that affect my life.")

- Hierarchist (e.g., "Decisions about the environment should be left to the experts.")

- Individualist (e.g., "In a fair system, no one has the right to tell me what to do.")

- Egalitarian (e.g., "If people were treated more equally, we would have fewer problems.")

- Technological enthusiast (e.g., "A high technology society is important for improving our health and social well-being.")

- Cornucopian (e.g., "The earth is abundant and robust.")

- Catastrophist (e.g., "You can see signs everywhere that the end is near. A great collapse and massive die-off is inevitable.") 
Some of these worldviews are more consistent with a positive view toward sustainability than others. For example, the "catastrophist" view that "the end is near" for earth should sensitize individuals to the need for environmental protection and stewardship. On the other hand, worldviews can also inhibit people from reacting positively toward sustainability, particularly if one's worldview is markedly pessimistic or leans in the direction of viewing individual action as futile in light of what may seem to be the inevitable consequences of human impacts on nature.

A good example is the "fatalist" worldview, an outlook which many people hold at least in some situations or in some contexts of their lives. This perspective need not necessarily be interpreted pejoratively to mean personal defeat. Fatalistic thought is a common means of interpreting the world and embodies the sense of inevitability that is present in most of the world's historical religions. Modern (and non-religious) fatalism resides in many secular views about apocalyptic events, such as nuclear war and environmental destruction. For example, in a 1984 Yankelovich poll, $39 \%$ of a public sample agreed that "When the Bible predicts that the earth will be destroyed by fire, it's telling us that a nuclear war is inevitable" (Jones 1985). In an extensive survey study of the views of young people (i.e., 17,000 high school seniors) about the future of humanity, more than one-third agreed with the statement that "Nuclear or biological annihilation will probably be the fate of all mankind within my gentration" (LaFarge 1987). Wojcik (1997), in a comprehensive review of various apocalyptic theories, notes that in traditional religious apocalypticism, "Faith and fatalism are ... interwoven into the fabric of apocalyptic thought: a profound fatalism for a world believed to be irredeemably evil is entwined with the faith for a predestined, perfect age of harmony and human fulfillment." However, secular apocalypticism appears devoid of an underlying redemptive meaning and moral order, and thus is "characterized by a sense of hopelessness and despair."

The sense of the inevitability of an apjroaching apocalypse is a major attitudinal theme for a significant portion of the American public which may make it difficult to convince them that painful policies to achieve sustainability are worthwhile. Within this theme, catastrophic occurrences bring about devastation on a vast scale, destroying most of humanity and its trappings. Along with this 
destruction comes a cleansing and a rebirth, and (in many themes) a survival of the righteous or the "true believers." Thus, in the apocalyptic view, the world is not a continuous process of growth and evolution, but a cyclical process of expansion and devolution, in which the future is finite and inevitable. As philosopher and theologian Martin Buber (1957) notes, in apocalyptic thought "everything is predetermined, all human decisions are only sham struggles" (p. 201).

In part, some of the problems associated with implementing social policies regarding sustainability reside in the schism individuals experience from competing worldviews. Though the public is quite supportive of efforts to restore the environment (as evidenced by their endorsement of attitude statements), their individual propensity to act can be compromised by other attitudes and views that suggest a belief in either a personal incapacity for effecting real change or the belief in an inevitable future that is simply a matter of fate. Indeed, many of the images that have been used to identify environmental problems may actually contribute to this sense of fatalism. For example, most images in the media are those of environmental catastrophe. While images of disaster and environmental collapse can serve to draw attention to environmental problems, they do not directly suggest or indicate the behaviors needed to produce the opposite state of the image. These images may actually confirm apocalyptic beliefs, at least for some, thereby exacerbating their feelings of the futility of human action in the face of what they see as the ultimate fate of humanity.

\subsection{DEFINITIONS OF WELL-BEING}

Definitions of human well-being and quality of life are highly diverse and variable, and sometimes inconsistent with the principles of sustainability. An important concept in social research is quality of life. Beginning in approximately the late 1950's, social scientists have invested significant energy in developing "social indicators" that could be used to measure quality of life. At the time, a number of "economic indicators" existed to provide information on the health of the economy, but there was a need for a corresponding set of indicators of social well-being. Early sets of social indicators tended to focus on publicly-available statistics, such as infant mortality rates and 
unemployment rates. Presumably, such rates should be correlated with quality of life (e.g., lower infant mortality equals higher quality of life and greater social well-being). Though such measures are putatively objective, they can be difficult to interpret. For example, a community may have a relatively low unemployment rate because of a new factory that has been sited there. However, the factory may also lead to increased traffic congestion, air pollution, water utilization, waste products, etc. Thus, by traditional "objective" measures quality of life is higher, but the experienced quality of life of community members may actually be lower than before the factory was sited.

In recent years, increased attention has been given to quality of life measures that are "subjective" and that attempt to capture quality of life and well-being as it is actually experienced by people. These measures are subjective in that they involve (usually through surveys) asking people for subjective assessments of the quality of their own lives. Such measures have the potential advantage of being made by the individuals themselves, rather than requiring a third party to make subjective judgments about "objective" data, as would be the case in deciding whether more jobs in a community is better than decreased environmental pollution. A number of different measures has been proposed and studied, including a "happiness" measure (e.g., Gurin et. al. 1960), Campbell's overall life satisfaction measure (Campbell et. al. 1976), and the multidimensional measures of Andrews and Withey (1976).

Subjective measures, however, have the tendency to produce reactive responses and very often correlate more strongly with highly situational factors in people's lives, rather than with their broader well-being. However, recent research in measures of quality of life generally supports the conclusion that people's assessments of their well being are formed from both their personal characteristics as well as their perceptions of their environment (e.g., Jeffres and Dobos 1995). Thus, subjective measures of quality of life tend to correlate with measures of satisfaction in various "domains" of life, such as municipal services, safety from crime, personal income, and family well-being. However, these domains tend to be relatively local, such as at the family or 
community level. Life satisfaction as a function of the quality of larger domains (e.g., quality of biodiversity) remains unexplored, though in all likelihood such correlations would be low.

What would be required for people's personal sense of well-being to be strongly associated with the elements of sustainability? First, intuitive conceptualizations of quality of life are highly linked to economic variables (e.g., personal income) or to variables that are indirectly related to economics (e.g., leisure travel). Though most quality of life measures correlate only modestly with personal income, the link between well-being and economics is strong even if it is not directly measurable in terms of personal wealth. Most prescriptions for sustainability are global in their scope and require individuals to appreciate and gain satisfaction from improving environmental conditions on the largest of scales. However, quality of life research tells us that the vast majority of people perceive and value a much more local environment that is more "social" in its characteristics than "natural." Thus, a challenge for sustainability is to represent its prescriptions in terms that better fit the milieu within which people assess their personal well-being.

\subsection{TIME FRAMES}

The time frames implied within frameworks of sustainability are, for the most part, beyond those individuals normally consider. The conditions that have led to the need for sustainability prescriptions have taken centuries of human activities to create. Likewise, the remedies for improving the outlook for sustainability will take centuries to implement, although many people believe that we have much less than a century to reverse present trends. The vastness of these time frames spans generations of human lives, and eclipses not only the life spans of individuals but, for the most part, their social memory (e.g., family histories). Few, if any, individual decisions and actions are undertaken with a consideration of a time span much beyond that of a single human life. One exception is the case of estate planning, where individuals may through extremely diligent efforts anticipate the future financial needs of their progeny and set in place trusts or other mechanisms to endow future wealth. Though research has shown that people are sensitive to the 
impacts of current technological activities on future generations (e.g., Gregory and Mendelsohn 1993), actual behaviors with regard to technology and the environment are based on considerations within a relatively short and near-term time perspective. Indeed, it is possible that the vast time frames implied by most theories of sustainability actually serve to discourage people from leading lives that would be beneficial to sustainability goals because they imply a futility of the individual's actions within the short term of their life.

A challenge for all prescriptive theories of sustainability is to render them in terms that are meaningful for the time frames that individuals are most accustomed to considering. Alternatively, more effort needs to be expended in educating people in how to think in terms of larger time frames, particularly time frames beyond that of average human longevity. Success for the efforts will be hard won as they will have to overcome increasingly smaller personal attention spans and the quickening pace of change in the business world.

\subsection{DIFFICULT DECISIONS}

Sustainability decision making is extraordinarily difficult for individuals. In many ways, for individuals to act in accord with prescriptions for sustainability involves making conscious decisions concerning lifestyle changes. For example, deciding to lead a life of energy conservation could involve major changes in one's use of transportation resources by working more at home, making greater use of public transportation, or riding a bicycle on more occasions. Sometimes these decisions involve trade-offs: for example, bicycles are more energy efficient, but expose the rider to greater personal risk of injury. Public transportation pollutes the air less than individual automobiles, but entails more time and inconvenience. Working at home reduces the need to utilize an automobile, but involves greater personal economic cost and increases the need for other technologies to communicate with co-workers (e.g., telephones, faxes). These decisions involve complex trade-offs that are difficult to make. Moreover, it isn't always clear that one's sustainability efforts will actually yield a positive result. For example, people can reduce their need 
for automobiles (which consume energy, pollute the environment and utilize a great deal of land for roadways) by working more at home, but that can require additional technology which itself utilizes (either directly or indirectly) environmental resources. Thus, if an individual buys a new and better computer for their home office, thereby reducing the number of days a week they need to drive into a city office, is that decision a net benefit in terms of sustainability? Unfortunately, current theories of sustainability offer little help in assessing this question as it pertains to individual decision making.

A problem that plagues many personal decisions that have social implications is the conflict between social good and individual gain. It can be argued that, in principle, all personal decisions are actually social decisions since every personal decision will have some implications for society. The fundamental nature of this dilemma has been described by Hardin (1968) as "the tragedy of the commons." The essence of Hardin's view is captured in the following synopsis of his original essay:

Picture a pasture open to all. It is expected that each herdsman will try to keep as many cattle as possible on (this) commons ... What is the utility . . of adding one more animal? ... Since the herdsman receives all the proceeds from the sale of the additional animal, the positive utility (to the herdsman) is nearly $+1 \ldots$ Since, however, the effects of overgrazing are shared by all the herdsmen, the negative utility for any particular decision-making herdsman is only a fraction of -1 . Adding together the ... partial utilities, the rational herdsman concludes that the only sensible course for him to pursue is to add another animal to (the) herd. And another; and another... Therein is the tragedy. Each man is locked into a system that (causes) him to increase his herd without limit - in a world that is limited. . . Freedom in a commons brings ruin to all. (Hardin 1968, p. 1244)

Dawes and others (e.g., Dawes, McTavish, and Shaklee 1977) have found that in experimental situations where individuals are confronted with choices involving personal gain versus gain to a group of which they are a part, that people will "defect" and opt for choices that maximize their personal gain over that of the group, even when they are aware that they will ultimately suffer the 
consequences of group loss. Current prescriptions for sustainability have largely ignored this aspect of human behavior and have tended to assume (at least implicitly) that individuals will tend to act in a manner that is consistent with the greater social good, assuming that they are aware of what that "good" is.

\subsection{OBSERVATIONS}

Social change occurs as the result of the collective action of individuals. To the degree that individuals are empowered and capable of acting with understanding and awareness, social change will come more quickly. Prescriptions for social change, such as sustainability, are more tractable to the degree that they are meaningful to individuals. Our review in this section has yielded a somewhat pessimistic assessment of sustainability prescriptions in this regard. For the most part, the context within which individuals form attitudes, make decisions and live their lives is vastly different from the global and futuristic perspective from which sustainability prescriptions draw their meaning. This is not to say, however, that individuals cannot act in a manner consistent with such prescriptions, or that the characteristics of human psychology render theories of sustainability unimplementable. From an individualistic perspective, a key challenge for the future of sustainability theories is to refine their prescriptions with greater sensitivity to implications for personal actions and within the context of short-term and long-term impacts for the individual on a personal level and on a community level. 


\section{CONCLUDING OBSERVATIONS AND RECOMMENDATIONS}

This report critically examines the concept of sustainability and the role of communities and individuals in meeting its precepts. Our review of the broad literature on sustainability reveals an exceedingly complex concept is associated with a plethora of challenging prescriptions. The assessment of Section 3 concludes that communities have: limited abilities to meet many of the most important sustainability prescriptions; some ability to meet many other prescriptions; and little ability to influence or control their external environments. The assessment of Section 4 concludes that individuals' abilities to meet sustainability prescriptions are similarly hampered.

Table 2 presents our views of the level of empowerment communities and individuals have with respect to the thirteen sustainability prescriptions distilled in Section 2. In this discussion, by empowerment we mean the ability, if so motivated, for communities and individuals to be able to exert some control or behave in ways to achieve the precepts of a sustainability prescription and have those achievements contribute greatly to meeting global targets for the prescription. Individual empowerment related to the controlling population prescription is very high because individuals have complete control over their reproductive decisions and, in the aggregate, can completely meet any global targets for this prescription, if so motivated. On the other hand, community empowerment related to this prescription is none because controlling human fertility is not within the control of communities, at least in the United States. This definition of empowerment allows for the contributions of others, especially industry, to meet global targets for many of the prescriptions (e.g., recycling, limiting resource use).

Overall, communities and individuals acting together have the potential to contribute to the achievement of most of the sustainability prescriptions. As mentioned above, while communities have no power to control population at the level of fertility, individuals are so empowered. In addition, while individuals themselves cannot ensure that the basic needs of every human being are met, people working together in comrnunities can meet this prescription. On the other hand, 
communities and individuals have limited ability to protect biodiversity, constrain the pace of change, and reduce pollution, because these activities need the cooperation of many communities, result from the aggregate activities of a globalized world, and require the regulation of private industry beyond normal community empowerment, respectively.

Table 2. Levels of community and individual empowerment to meet sustainability prescriptions.

\begin{tabular}{|c|c|c|}
\hline Prescription & $\begin{array}{c}\text { Level of } \\
\text { Community Empowerment }\end{array}$ & $\begin{array}{c}\text { Level of Individual } \\
\text { Empowerment }\end{array}$ \\
\hline $\begin{array}{l}\text { Limit resource use - } \\
\text { e.g., energy, water, } \\
\text { minerals }\end{array}$ & $\begin{array}{l}\text { Low: only in limited situations can } \\
\text { control limited number of resources } \\
\text { (e.g., energy and water) }\end{array}$ & $\begin{array}{l}\text { Medium: can voluntarily reduce } \\
\text { energy and water use; industry } \\
\text { must contribute }\end{array}$ \\
\hline reduce pollution & $\begin{array}{l}\text { Low: typically subservient to state } \\
\text { and federal laws }\end{array}$ & $\begin{array}{l}\text { Medium: in most cases, can } \\
\text { only control indirectly }\end{array}$ \\
\hline recycle & $\begin{array}{l}\text { Medium: can implement } \\
\text { community programs, but most } \\
\text { waste is industrial }\end{array}$ & $\begin{array}{l}\text { Medium: can recycle most } \\
\text { household wastes, but most } \\
\text { waste is industrial }\end{array}$ \\
\hline control population & $\begin{array}{l}\text { None: not within scope of } \\
\text { community empowerment }\end{array}$ & $\begin{array}{l}\text { High: completely within } \\
\text { individual control }\end{array}$ \\
\hline protect biodiversity & $\begin{array}{l}\text { Low: scale of control is limited, but } \\
\text { can save selected habitats }\end{array}$ & $\begin{array}{l}\text { Low: scale of control is very } \\
\text { limited but can contribute } \\
\text { through 'backyard' efforts }\end{array}$ \\
\hline $\begin{array}{l}\text { constrain pace of } \\
\text { change }\end{array}$ & $\begin{array}{l}\text { Very low: cannot control external } \\
\text { world }\end{array}$ & $\begin{array}{l}\text { Very low: cannot control } \\
\text { external world }\end{array}$ \\
\hline limit consumerism & $\begin{array}{l}\text { Low: can only control internal } \\
\text { purchases }\end{array}$ & $\begin{array}{l}\text { Very High: completely within } \\
\text { individual control }\end{array}$ \\
\hline conserve land & $\begin{array}{l}\text { Medium: zoning laws useful but } \\
\text { much land cannot be controlled }\end{array}$ & $\begin{array}{l}\text { Medium: individuals can } \\
\text { voluntarily conserve land }\end{array}$ \\
\hline
\end{tabular}




\begin{tabular}{|l|l|l|}
\hline \multicolumn{1}{|c|}{ Prescription } & \multicolumn{1}{c|}{\begin{tabular}{c}
\multicolumn{1}{c|}{ Level of } \\
Community Empowerment
\end{tabular}} & \multicolumn{1}{c|}{$\begin{array}{c}\text { Level of Individual } \\
\text { Empowerment }\end{array}$} \\
\hline practice strong & $\begin{array}{l}\text { High: within political capabilities if } \\
\text { so motivated }\end{array}$ & $\begin{array}{l}\text { High: can create strong } \\
\text { democracy through determined } \\
\text { public participation }\end{array}$ \\
\hline $\begin{array}{l}\text { achieve intra- and } \\
\text { intergenerational equity }\end{array}$ & $\begin{array}{l}\text { Medium: clifficult concept to grasp; } \\
\text { reach of a single community is } \\
\text { limited }\end{array}$ & $\begin{array}{l}\text { Low: difficult concept to grasp; } \\
\text { reach of an individual is mostly } \\
\text { limited to family }\end{array}$ \\
\hline meet basic human needs & $\begin{array}{l}\text { Very high: within social welfare } \\
\text { community prerogatives }\end{array}$ & $\begin{array}{l}\text { Medium: can meets the needs } \\
\text { of family and others but only in } \\
\text { limited numbers }\end{array}$ \\
\hline $\begin{array}{l}\text { adopt sustainable } \\
\text { personalities }\end{array}$ & $\begin{array}{l}\text { Medium: communities can develop } \\
\text { such visions }\end{array}$ & $\begin{array}{l}\text { High: generally within } \\
\text { individual choice }\end{array}$ \\
\hline $\begin{array}{l}\text { implement proper } \\
\text { decision making } \\
\text { heuristics }\end{array}$ & $\begin{array}{l}\text { Medium: vithin community } \\
\text { prerogatives, theoretically, but may } \\
\text { be difficult to implement }\end{array}$ & $\begin{array}{l}\text { Medium: within rights to } \\
\text { advocate for in community }\end{array}$ \\
\hline
\end{tabular}

The goal of sustainability policy should be to implement programs to raise empowerment as much as possible given the limitations outlined in the above table. Specifically, the policies need to target the constraints discussed in both Sections 3 and 4. Listed below are eight general recommendations.

\subsection{TRANSLATE GLOBAL SUSTAINABILITY PRESCRIPTIONS}

If people are serious about sustainability, then it can be argued that global sustainability prescriptions need to be translated into guidelines, if not specific numerical targets, for communities and individuals. These targets could be seen to complement any sustainability indicators that communities already have in place. As indicated above, sustainability targets can be 
associated with many of the sustainability prescriptions. For example, how much does energy need to be reduced per capita? Water use? Consumption of other resources? How can land be best used with respect to sustainability prescriptions? What might be a target population for a community (developed as part of a larger population assessment)? Logically, such targets are needed in order to better focus community-level and individual sustainability decision-making. In addition, such targets are needed to operationalize an integrated global sustainability effort across many scales. Without such targets, behavior will only receive limited direction. It can be strongly argued that without targets, it will only be by chance that sustainability will be achieved.

The difficulty for a country such as the United States to set, much less achieve, national targets for these types of sustainability prescriptions cannot be overestimated. Technical and political challenges abound. With respect to the former, significant uncertainties afflict analytical efforts to set such targets. With respect to the latter, allocation of targets among communities is sure to instill much conflict because targets will surely differ based on local contexts. Imposing targets on individuals, especially with respect to fertility, is probably politically impossible. These extreme difficulties only grow by orders of magnitude when global sustainability targets are addressed.

However, these difficulties should not prevent people from carrying out the analyses so as to inform and educate everybody about the state-of-the-world with respect to the sustainability prescriptions and how communities and individuals can contribute. This work, in turn, will help to clarify the principles and applications of sustainability, and even help to evolve the concept as difficulties and experiences gained by communities and individuals help shape global and academic notions of sustainability.

\subsection{CLARIFY RESPONSIBILITIES FOR SUSTAINABILITY}

Responsibilities for meeting sustainability prescriptions need to be appropriately undertaken by each level of social organization, from international institutions to individuals. What exact 
responsibilities each level of social organization should embrace to achieve sustainability prescriptions is an open research question and is currently subject to intense political debate.

Generally speaking, it was suggested herein that communities and individuals do not have much if any, control over: the development of technology, biodiversity, pollution and other behaviors attributable to the private sector (especially multinational corporations), societal achievement of intra- and intergenerational equity, and constraining the pace of change. National and international communities, one can argue, certainly can work toward meeting the first four prescriptions. It may be beyond anyone's power to manage the pace of change. However, it may be the case that managing the quality of change toward sustainability is the result of other efforts, and not a thing to tackle directly.

Communities can focus on those areas highlighted in Table 2 that they theoretically are empowered to deal with; similarly for individuals. To guide such an effort, however, will require a mapping between the various component prescriptions for sustainability and the various levels of social organization (e.g., nations, regions, communities, individuals). Such a mapping, if systematically carried out, would reveal where the links between sustainability prescriptions and particular social organizations are strong and where they are weak. For example, biodiversity may be a prescription best implemented at the regional or national level, while energy conservation as a sustainability prescription may be better suited to communities and individuals. Further decomposition of these prescriptions could be undertaken along with the development of a taxonomy of social organizations suited to implementing them.

\subsection{COORDINATE ACROSS SCA.LES}

Actions to achieve sustainability prescriptions need to be coordinated across scales. It is not enough to assign responsibilities for sustainability to various types and levels of organizations. From a systems viewpoint, actions taken at one level of scale to meet a specific prescription (such as implementation of a tax) may have negative or positive feedbacks on actions at other levels of 
scale to achieve this or other prescriptions. To ameliorate negative feedbacks, coordination is needed to implement counterbalancing actions and policies.

Coordination across scales is a daunting task. The small number of attempts at international and regional coordination involving numerous political entities amply demonstrate the difficulties of coordination within scales. Across scale coordination will require institutional change, if not the creation of new institutional forms. Non-governmental organizations need to play an important role in the coordination process. They can be information brokers and conduits. They can be coordination agents by convening appropriate people together at the appropriate times to discuss coordination issues.

\subsection{EMPOWER COMMUNITIES AND INDIVIDUALS}

Communities and individuals need improved empowerment to meet sustainability responsibilities. Discussions related to this recommendation need to be clear on whether it is better to help communities and individuals more quickly and effectively adapt to the multifarious influences of the external world or whether it is better to work toward reducing the ability of the external world to have such influences. In the first case, the position is that sustainability is best achieved if every community and individual is as highly networked into the external, global world as possible. Such high density networking, it can be argued, will lead to maximum resilience of the entire system. In the second case, the position is that sustainability is best achieved through local subsistence. Autonomous communities, it can be argued, will be more resilient because they have less external influences to plan to overcome. It may be possible to do both, but only if communities and individuals can deal with the two paradigms simultaneously.

Models of sustainability need to take greater account of the lack of empowerment at the community level. Most policies regarding sustainability stress the importance of healthy communities as a basis for meeting society's future resource needs. However, communities are 
very often (if not for the most part) relatively unempowered to assist and guide community members. Recent trends in grass-roots tax initiatives have left many communities without the power to raise sufficient revenues to meet local needs, much less to implement community-based programs to promote sustainability. Furthermore, while the structure of our democratic society draws its representative base from society at large (e.g., individuals, local congressional districts), the power to develop and implement policy often comes from the top down. Thus, communities are relatively unempowered to act on their own with regard to environmental laws and regulations, all of which have to meet standards no more stringent than those of higher governmental authorities. For example, no community can pass a law declaring a species as endangered, nor can it pass laws banning environmental damaging natural resource extraction activities, such as clear-cutting of forests.

It is within the power of states to grant communities more powers to progress toward sustainability. States could grant comrnunities more power to enact stronger zoning laws to conserve land and water. Communities could be allowed to experiment with different forms of government. In addition, communities could work to slowly but continuously change the built environment to be more environmentally friendly. Lastly, communities, through empowered citizens, can elect and direct their state and federal representatives to adopt policies and programs that better allow communities to make progress toward sustainability prescriptions.

Policy implementation needs to take greater account of the constraints on individual action. People are limited in time and resources. This places constraints on what they can realistically do to accomplish sustainability goals. Some social groups, families, and individuals may be more constrained than others. In some circumstances, these are marginalized individuals, families, or cultural groups. Unfortunately, these groups are the ones that are most often impacted by the failure of society to meet sustainability needs.

Policies that are intended to accomplish sustainability objectives need to take implementation guidance from the realities of peoples" lives. This may mean tailoring or crafting policies that 
theoretically achieve less in the aggregate over a given time, but from a practical perspective accomplish more because they are more readily implemented at the level of the individual decision maker.

\subsection{INTEGRATE COMMUNITY AND INDIVIDUAL SUSTAINABILITY EFFORTS}

The basic argument is that there are significant benefits to be gained by communities and individuals by working together to progress toward sustainability objectives. Positive actions can result in positive feedbacks. A group of citizens can influence the community to initiate small scale information campaigns to educate others about sustainability. A larger critical mass of citizens can then work to have the community devote financial resources to implementing sustainability programs, greening of the tax code, establishing local franchises for electric services, setting recycling fees, etc. Citizen backing of community sustainability programs is essential for programmatic credibility and ultimate success.

More specifically, communities and citizens can work together in many ways to improve environmental citizenship (Tonn and Petrich 1997). For example, collaborative programs can be implemented where citizen volunteers can collect environmental data needed to monitor key sustainability indicators. Community government can provide leadership functions to establish environmental neighborhoods and life-long education programs for citizens. Both can work with the private sector to allow employees to use phones and computers, for example, for environmental citizenship purposes. Advanced community-based community networks can be used to facilitate these and many more initiatives. 


\subsection{REFRAME SUSTAINABILITY PRESCRIPTIONS}

Sustainability prescriptions aimed at communities and individuals need to be reframed to improve their understandability and relevance. Theories of sustainability need to be constructed with more of a "bottom-up" orientation. That is, we need to identify theories and prescriptions for sustainability based on our knowledge of individual behavior and its determinants, thus a bottom-up rather than a top-down theory. Current prescriptions for sustainability are top down, like macroeconomic theory and other systemic theories that assume individual actors will abide by the general axioms of the model (e.g., economic rationality, altruism, value for future generations).

For sustainability prescriptions to have an impact on self-directed, personal decision making, they need to be more image oriented. The prescription has to have a goal state or objective that is not only understandable, but that is "imaginable." The image has to be rich and contain within it not just rules or objectives, but a basis for action across many different situations. People have to have a sense that their individual behavior is leading to a world that they can "picture in their head." They have to be able to imagine or place themselves in that world through their direct actions (Boulding 1956). For example, communities that desire to improve their sustainability through land conservation practices could develop visual models of their community under various land use scenarios that are consistent with sustainability prescriptions. Individuals who wish to practice water conservation in and around their home need images of, for example, landscaping practices that make minimal use of water. Another good example is the fish tattoos painted on roads next to storm water runoff drains that indicate that eventually, everything put into the drain will reach the oceans. Such images need to be developed, publicized and made available.

\subsection{DEVELOP BETTER SUSTANABIITY INDICATORS}

Better indicators for sustainability need to be developed and implemented at the community and individual levels. Prescriptions for sustainability are replete with parameters that specify change: 
conserve, limit, reduce, control. However, most of these parameters are expressed in terms that have relatively little (or no) relevance for community or individual actions. How much conservation is enough? How effective are we being in our recycling efforts? How much energy can I use today and still be within a sustainability prescription? How much energy have I used today? Current sustainability prescriptions leave such questions without answers and leave both communities and individuals without indicators for gauging the outcomes of their sustainability efforts. In other activities in society, indicators serve an important role in providing information relevant to action. For example, gasoline gauges on automobiles tell drivers how much fuel remains so they can decide when to refuel. Speedometers indicate to drivers how fast they are going and help them comply with speed laws. However, sustainability indicators with equal relevance to individual and community behavior are generally absent. Or, when they are present, they are in a form that has limited relevance. For example, electric bills from utility companies indicate total electricity consumption over the billing period, usually in terms of kilowatt hours. Yet, few people are aware in a real-time sense of how much energy they are consuming at the moment. Though automobiles have an indicator to tell the driver how much fuel is remaining in the tank, there is no indicator to tell the driver the rate at which fuel is being consumed (or the current miles per gallon). Thus, not all indicators are as informative as they could be.

Better indicators of the progress of achieving sustainability goals need to be developed. Some of these indicators could be at the "micro" level, such as indicators that individuals or communities might use to monitor the effectiveness of their own actions. Others could be at a more "macro" level, and could serve to indicate more generally how well sustainability prescriptions are being met. Such an indicator could be modeled after that published in The Bulletin of the Atomic Scientists, the cover of which regularly carries an image of a clock, with the minute hand indicating a judgment about how close the world is to global nuclear catastrophe. Though such an indicator is not a precise measure by any means, it does serve to convey the assessment of professionals. Similar indicators for sustainability could be developed for regions (and communities), and even for individuals in specific contexts. For example, individual homes using unusual amounts of energy, or using energy in excess of sustainability prescriptions could be coded on their monthly 
energy bill. Other indicators could be developed that communicate how much reduction in natural resources needs to be achieved to meet sustainability goals.

Research has shown that individuals do respond to conservation measures in specific contexts. For example, energy conservation prograrns that have focused on monitoring and feedback approaches to appraise residences of their energy utilization have generally led to greater conservation, as have programs to increase car pooling and recycling (see Geller 1987, for a review). However, these programs require careful analysis of behavior (they often include some experimental work) and they must include incentives that are important and meaningful to individuals (e.g., rate reductions). Moreover, the programs have to remain continually supported for them to be effective. Thus, successful implementation of prescriptions for sustainability will require sustainable programs.

Also, regarding the pace-of-change comment above, it seems that pace-of-change could be a macro-indicator of the success of sustainability efforts. It might be useful at some point to speculate how such a measurement or indicator could be constructed. Probably a multidimensional indicator would be appropriate that aggregates a number of factors, including population growth, natural resource utilization, environmental pollution, and biodiversity. One can probably come up with measures for all of these things (and for their components), perhaps scaling them based on historical trends to get an index of change. Initially, they could be equally weighted in the index, but expert judgment could be used to provide differential weights. Confidence bounds could be put around the index. As for the properties of the index itself, it might be desirable to have a scale that centers on zero, with negative values indicating return to prior states (e.g., air pollution less than baseline). 


\subsection{IMPLEMENT EVALUATION PROGRAMS}

Vigorous and rigorous evaluation, learning, and societal memory programs need to be implemented to support improved sustainability over the very long term. With respect to meeting sustainability prescriptions, there are many, many approaches that can be taken. The challenge is determining which approaches are most effective in what situations and which approaches fail in what situations. The problem is that the effectiveness of programs or the wisdom of decisions may not become detectable until many years after the programs are implemented or the decisions made. Certainly, implementing processes to watch and evaluate and detect poses practical difficulties. Additionally, assuming such processes could be put in place, an overriding concern is whether anyone would be able to learn from the assessments. In most cases, people originally involved with the programs and/or decisions will be gone. Thus, those most able to appreciate and learn from the assessments will not be around to do so. And of course; they will not be able to pass such knowledge. Thus, societal memory programs, which are capable of accumulating knowledge across any one individual's experiences and passing such knowledge on from one person to the next, are necessary for the incremental improvement of especially community sustainability efforts over time.

This recommendation implies that a societal memory for sustainability needs to be created, or created within existing political processes. For example, constitutional amendments are a form of societal memory. Statutes are another. Religious practices are a third. So, there are mechanisms that exist for transmitting messages from the past to the future. One can envision community digital libraries that hold video documentation of interviews with people about why they decided things as they did as a foundation for a societal memory system. Maybe each citizen could have a 'digital mentor' to help them learn over time. This recommendation is open for additional ideas. 


\subsection{FINAL OBSERVATIONS}

It is truthful to state that the analyses presented above are rather sobering to us in their conclusions as to the limitations of communities and individuals in meeting sustainability prescriptions.

However, with leadership and statesmanship at all levels of society, combined with the evolution of new social norms and institutions, the sustainability prescriptions can be achieved. Important research needs to be conducted in each of the recommendation areas (e.g., to set targets, to build effective societal memory programs) as well as in cross-cutting areas, such as using incentives to guide behavior.

Communities are probably the best hope for sustainability prescriptions, although it can be concluded that profound change will be needed at the community level for this to happen. If communities are successful in making progress towards sustainability, their influence would be a multiplier of individual efforts. Communities provide a framework within which individuals can receive clear goals and objectives, as well as indicators. Communities serve to organize and give meaning to individuals' lives. Though communities cannot influence all sustainability parameters, many of those they can influence could be measured. Furthermore, behavioral interventions at the individual level appear to work best when developed and supported at the community level. From this perspective, a viable direction forward with regard to sustainability prescriptions appears to be greater focus on defining sustainability in terms of factors that communities and individuals are empowered to act upon. We propose that greater effort be devoted to decomposing sustainability prescriptions into subdivisions that have direct implications for both community programs and individual behavior. To a limited degree this has been done with regard to behaviorally-oriented programs for energy conservation, recycling and the like. However, these programs typically lack links to larger models of sustainability and can easily fail to engage both communities and individuals in seeing the relevance of their local actions for global outcomes.

Two last observations relate to setting sustainability prescription targets for communities and individuals. First, target setting implies a global approach to sustainability. Second, from a political 
perspective, the development of many important targets seems quite difficult, if not virtually impossible, to succeed without very strong leadership and commitment. In areas of the country where scarce resources need to be allocated, difficult controversies often arise. Such controversies would only escalate as additional items are added to the agenda and as negotiations involve more communities, regions, states, and finally countries. 


\section{ACKNOWLEDGMENTS}

We wish to greatly thank several people who graciously contributed much of their time and attention to reviewing draft versions of this report. These people are: Andrew Schiller, Margaret Lyday, John Peine, Alex Farrell, Dave Cash, Geri Spring, George Peterson, Dave Feldman, Lance McCold, Wolf Naegeli, Tom Stanton, and Marty Schweitzer. We also thank Sheila Moore for her assistance in preparing the report. 


\subsection{REFERENCES}

Atkinsson, A., "Developing Indicators of Sustainable Community: Lessons from Sustainable Seattle," Environmental Impact Assessment Review, Vol. 16, No. 4-6, pp. 337-351, 1996.

Andrews, F. M., and Withey, S., Social Indicators of Well-being: Americans' Perceptions of Life Quality, New York: Plenum, 1976.

Barlow, M., "Administrative Systems and Metropolitan Regions," Environment \& Planning C Government and Policy, Vol. 15, No. 4, pp. 399-411, 1997.

Bell, W., "Why Should We Care About Future Generations," in The Years Ahead: Perils, Problems and Promises, H. Didsbury (Ed.), World Future Society, Bethesda, Maryland 1993.

Bishop, R., "Economic Efficiency, Sustainability, and Biodiversity," Ambio, Vol. 22, No. 2-3, pp. 69-74, 1993.

Boulding, K., The Image: Knowledge and Life in Society, Ann Arbor, Michigan: University of Michigan Press, 1956.

Brehmer, B., Strategies in Real-time Dynamic Decision Making, in R. Hogarth (Ed.), Insights in Decision Making: A Tribute to Hillel J. Einhorn (pp. 262-279). Chicago: University of Chicago Press, 1990.

Brown, E., "In Fairness to Future Generations," Environment, Vol. 32, No. 3, pp. 6-11, 30-31, 1990. 
Brown, L., "Organizations for the $21^{\text {st }}$ Century: Cooperatives and New Forms of Organization" Canadian Journal of Sociology, Vol. 22, No. 1, 1997.

Buber, M., Pointing the Way: Collected Essays, Baltimore: Johns Hopkins University Press, 1957.

Burgess, J. and Harrison, C., "Actions Speak Louder Than Words," Town \& Country Planning, Vol. 66, No. 11, p. 282, 1997.

Buss, D. M., Craik, K. H., and Dake, K. M., Contemporary Worldviews and Perception of the Technological S, in V.T. Covello, J. Menkes, and J. Mumpower (Eds.) Risk Evaluation and Management (pp. 93-130), New York: Plenum, 1986.

Campbell, A., Converse, P. E., and Rodgers, W. L., The Quality of American Life: Perceptions, Evaluations, and Satisfactions, New York: Russell Sage Foundation, 1976.

Castle, E., Berrens, R., and Polasky, S., "The Economics of Sustainability," Natural Resources Journal, Vol. 36, No. 4, pp. 475-491, 1997.

Chapin, F., Torn, M., and Tateno, M., "Principles of Ecosystem Sustainability," American Naturalist, Vol. 148, No. 6, pp. 1016-1037, 1996.

Chiras, D., "Principles of Sustainable Development: A New Paradigm for the Twenty-First Century," Journal of Environmental Science Health - Environmental Carcinogenic Ecotoxicologial Review, Vol. 13, No. 2, pp. 143-179, 1995.

CIDA, Sustainable Development, Policy Branch, Canadian International Development Agency, Ottawa, 1991. 
Concern, Inc., Sustainability in Action: Profiles of Community Initiatives Across the United States, Washington, D.C. 1998.

Cotgrove, S., Catastrophe or Cornucopia: The Environment, Politics and the Future, New York: Wiley, 1982.

Constanza, R. and Patten, B., "Defining and Predicting Sustainability," Ecological Economics, Vol. 15, No. 3, 1995.

Daly, H. E., "Toward Some Operational Principles of Sustainable Development," Ecological Economics, Vol. 2, pp. 1-6, 1990.

Dansereau, P., "Interdisciplinary Perspective on Production-Investment-Control Processes in the Environment," UNESCO, Vancouver Declaration: Final Report of the UNESCO Symposium of Science and Culture for the $21^{\text {st }}$ Century: Agenda for Survival, Canadian Commission for UNESCO, Ottawa, pp. 55-100, 1990.

Dansereau, P., "Harmony and Disorder in the Canadian Environment," Occasional Paper No. 1, Canadian Environmental Advisory Council, Environment Canada, Ottawa, 1975.

DesJardings, J., Environmental Ethics: An Introduction to Environmental Philosophy, Belmont, CA: Wadsworth Publishing Co., p. 90, 1993.

Doob, L., Sustainers and Sustainability: Attitudes, Attributes, and Actions for Survival, Westport, CT: Praeger, p. 1, 1995.

Dovers, S., "Uncertainty, Ecology, Sustainability, and Policy," Biodiversity Conservation, Vol. 5, No. 10, pp. 1143-1168, 1996. 
Dovers, S. and Handmer, J., "Contradictions in Sustainability," Environmental Conservation, Vol. 20, No. 3, pp. 217-222, 1993.

Dake, K., "Orienting Disposition in the Perception of Risk: An Analysis of Contemporary Worldviews and Cultural Biases," Journal of Cross-Cultural Psychology, Vol. 22, pp. 61-82, 1991.

Dawes, R. M., McTavish, J., and Shaklee, H., "Behavior, Communication, and Assumptions About Other People's Behavior in a Commons Dilemma Situation," Journal of Personality and Social Psychology, Vol. 35, pp. 1-11, 1977.

Dunlap, R. E., "Trends in Public Opinion Toward Environmental Issues: 1965-1990," Society and Natural Resources, Vol. 4, pp. 285-312, 1991 a.

Dunlap, R. E., "Public Opinion in The 1980's: Clear Consensus, Ambiguous Commitment," Environment, Vol. 33, pp. 9-37, 1991 b.

Ehrlich, P. and Holdren, J., "Impact of Population Growth," Science, Vol. 171, pp. 1212-1217, 1971.

Farrell, A., Sustainability and Choice: Theory with an Application in Energy Policy, Ph.D.

Dissertation, University of Pennsylvania, Philadelphia, PA, 1996.

Flyvbjerg, B., Rationality \& Power: Democracy in Practice, Chicago, IL: The University of Chicago Press, 1998.

Frankenfeld, P., "Simple Gifts: Complex Environmental Hazards and the Responsibility to Leave a Controllable World," Futures, Jan/Feb., p. 33, 1993. 
Geller, E. S., "Applied Behavior Analysis and Environmental Psychology: from Strange Bedfellows to a Productive Marriage, in D. Stokols \& I. Altman (Eds.), Handbook of Environmental Psychology: Vol. I., New York: John Wiley \& Sons, 1987.

Georgescu-Roegen, N., The Entropy Law and the Economic Process, Cambridge: Harvard University Press, 1971.

Gibbons, J., "Decisionmaking in the Face of Uncertainty," Arizona Journal of International and Comparative Law, Vol. 9, No. 1, pp. 231-252, 1992.

Gilroy, J., "Public Policy and Environmental Risk: Political Theory, Human Agency, and the Imprisoned Rider," Environmental Ethics, Vol. 14, No. 3, p. 228, 1992.

Golding, M., "Obligations to Future Generations," in Ernest Partridge, Ed., Responsibilities to Future Generations, Buffalo, NY: Prometheus Books, 1981.

Gregory, R., and Mendelsohn, R., "Perceived Risk, Dread, and Benefits," Risk Analysis, Vol. 13, pp. 259-264, 1993.

Grove-White, R., "Currents of Cultural Change," Town \& Country Planning, June, pp. 169-171, 1997.

Gurin, G., Veroff, J., and Field, S., Americans View Their Mental Health, New York: Basic, 1960.

Hardin, G., "The Tragedy of the Commons," Science, Vol. 162, pp. 1243-1248, 1968.

Harris, L., Public Worried About State of Environment Today and in Future, The Harris Poll, May 1989. 
Haughton, G. and Hunter, C., Sustainable Cities,. Jessica Kingsley, London, 1994.

Hodge, T., "Toward a Conceptual Framework for Assessing Progress Toward Sustainability," Social Indicators Research, Vol. 40, No. 1-2, pp. 5-98, 1997.

Holdgate, M., From Care to Action: Making A Sustainable World, Washington, DC: Taylor and Francis, 1996.

Hollender, J. (with L. Catling), How to Make the World a Better Place: 116 Ways You Can Make a Difference, New York: W.W. Norton \& Co., 1995.

Holmberg, J., Robert, K. H., and Eriksson, K.E., "Socio-ecological Principles for a Sustainable Society," in Getting Down to Earth: Practical Applications of Ecological Economics, $\mathbf{R}$. Constanza, O. Segura, and J. Martinez-Alier (Eds.), Washington, DC: Island Press, pp. 17-48, 1996.

Howarth, R. "Sustainability Under Uncertainty: A Deontological Approach," Land Economics, Vol. 71, No. 4, pp. 417-427, 1995.

Howarth, R. and Monahan, R., Economics, Ethics, and Climate Policy, Report No. NEI-SE-122, Stockholm Environmental Institute, Sweden, 1993.

Howarth, R. and Norgaard, R., "Environmental Valuation Under Sustainable Development," American Economic Review, Vol. 82, No. 2, pp. 473-477, 1992.

Hygeai Consulting Services, Changing Values, Changing Communities: $A$ Guide to the Development of Healthy, Sustainable Communities, Ottawa, Ontario, Canada, 1995. 
IUCN, UNEP, and WWF, "Caring for the Earth - A Strategy for Sustainable Living," International Union for Conservation of Nature and Natural Resources; United Nations Environment Programme; and the World Wildlife Fund, 1991.

Jasper, J. M., Nuclear Politics: Energy and the State in the United States, Sweden, and France, Princeton, NJ: Princeton University Press, 1990.

Jeffres, L. W., and Dobos, J., "Separating People's Satisfaction with Life and Public Perceptions of the Quality of Life in the Environment;", Social Indicators Research, Vol. 34, pp. 181-211, 1995.

Jones, L., "Reagan's Religion," Journal of American Culture, Vol. 8, pp. 59-70, 1985.

Kahneman, D., Slovic, P., and Tversky, A., Judgment Under Uncertainty: Heuristics and Biases. New York: Cambridge University Press, 1982.

Kennickell, A. B., Starr-McCluer, M., and Sunden, A. E., "Family Finances in the U.S.: Recent Evidence from the Survey of Consumer Finances," Federal Reserve Bulletin, Vol. 83, pp. 1-24, 1997.

Kinsley, M., "Collaborative Decision Making for Sustainable Development," Proceedings of the Conference on Designing for the Global Environment, Atlanta, GA, 1995.

LaFarge, P., The Strangelove Legacy: Children, Parents, and Teachers in the Nuclear Age, New York: Harper \& Row, 1987.

Lyday, M., "Assets, Challenges, and Teeds for Community Sustainable Development: Interview Results," National Center for Environmental Decision-making Research, University of Tennessee-Knoxville, Knoxville, TN, 1998 (draft). 
MacGregor, D. G., "Worry Over Technological Activities and Life Concerns," Risk Analysis, Vol. 11, pp. 315-324, 1991.

MacLean, D., In "Introduction to Conflicting Views on a Neutrality Criterion for Radioactive Waste Management" by D. Bodde and T. Cochran, University of Maryland, College Park, Center for Philosophy and Public Policy, Feb., p. 3, 1981.

McKelvey, M. and Rismiller, P., "Designing for Elegant Sufficiency or Superfluous Elegance," in Rethinking the Built Environment: Proceedings of the Catalyst '95 Design and Environment Conference, J. Birkeland (Ed.), Canberra, Australia, pp. 333-337, 1995.

Meadows, D., "Envisioning a Sustainable World," in Getting Down to Earth: Practical Applications of Ecological Economics, R. Constanza, O. Segura, and J. Martinez-Alier (Eds.), Washington, DC: Island Press, pp. 117-126, 1996.

Milbrath, L., Envisioning a Sustainable Society: Learning Our Way Out, Albany, NY: SUNY Press, 1989.

Miller, J., Living Systems, New York: McGraw-Hill, 1978.

Minnesota Planning Environmental Quality Board, "Sustainable Development: The Very Idea," 1998, 658 Cedar St., St. Paul, MN, (see http://www.mnplan.state.mn.us).

National Renewable Energy Laboratory, Sustainability Projects Resources for Future Generations, DOE/GO - 10095-041, Golden, CO, 1995.

New York Times, October 10, 1997, p. D1. 
Norton, B., "Sustainability, Human Welfare, and Ecosystem Health," Environmental Values, Vol. 1, No. 2, pp. 97-112, 1992.

Okubo, D., The Community Visioning and Strategic Planning Handbook, National Civic League, Denver, CO: National Civic League Press, 1997.

Olson, R., "Alternative Images of a Sustainable Future," Futures, Vol. 26, March, pp. 156-169, 1994.

Opschoor, J., "Institutional Change and Development Towards Sustainability," in Getting Down to Earth: Practical Applications of Ecoiogical Economics, R. Constanza, O. Segura, and J. Martinez-Alier (Eds.), Washington, DC: Island Press, pp. 327-350, 1996.

Oregon Benchmarks, 1998. See http://www.econ.state.or.us/opb/highlights/benchmark_tables.html.

Randers, J., "The Quest for a Sustainable Society - A Global Perspective," in The Notion of Sustainability and Its Normative Implications, G. Skirbekk (Ed.), Oslo, Norway: Scandinavian University Press, pp. 16-27, 1994.

Rapport, D. and Friend, A. "Towardis a Comprehensive Framework for Environmental Statistics: A Stress-Response Approach," Statistics Canada Catalogue 11-510, Minister of Supply and Services Canada, Ottawa, 1979.

Reed, M., "Locally Responsive Environmental Planning in the Canadian Hinterland: A Case Study in Northern Ontario," Environmental Impact Assessment Review, Vol. 14, No. 4, pp. 245-269, 1994. 
Rees, W. and Wackernagel, M., "Urban Ecological Footprints: Why Cities Cannot be Sustainable - and Why They Are a Key to Sustainability," Environmental Impact Assessment Review, Vol. 16, Nos. 4-6, pp. 223-248, 1996.

Roberts, D., "What is Sustainable Development?" Presentation at Oak Ridge National Laboratory, Feburary 19, 1998.

Robinson, J., Notes on Sustainable Society Project Indicator Diagrams, Department of Environment and Resource Studies, Waterloo: University of Waterloo, 1989.

Roger-Machart, C., "The Sustainable City - Myth or Reality?" Town \& Country Planning, February, pp. 53-55, 1997.

Sadler, B. 1988, "Impact Assessment, Development Planning and International Assistance in Post Brundtland Perspective," Proceedings of the International Workshop on Impact Assessment for International Development, International Association for Impact Assessment, Vancouver, pp. $775-787$.

Sagoff, M. 1994, “Should Preferences Count?” Land Economics, Vol. 70, No. 2, pp. 127-144.

Santa Monica, 1998. See http://pen.ci.santa-monica.ca.us/environment/policy/indicat3.htm.

Schiller, A. 1998, Personal communication.

Schrader-Frechette, K., "Ethical Dilemmas and Radioactive Waste," Environmental Ethics, Vol. 13, No. 4, p. 339, 1991.

Schumacher, E. F., Small is Beautiful: Economics as if People Mattered, New York: Harper \& Row, 1973. 
Sessions, K., "Building the Capacity for Change," EPA Journal, Vol. 19, No. 2, pp. 15-25, 1993.

Sitarz D. (Ed.), Agenda 21: The Earth Summit Strategy to Save Our Planet, Boulder, CO: Earthpress, 1993.

Sloep, P., "The Impact of 'Sustainability' on the Field of Environmental Science," in The Notion of Sustainability and Its Normative Implications, G. Skirbekk (Ed.), Oslo, Norway: Scandinavian University Press, pp. 29-55, 1994.

Slovic, MacGregor, and Dreman, Survey of Investor Confidence, Decision Research Report, Eugene, OR: Decision Science Research Institute, 1998.

Soersensen, B., "Strategy for a Rich, Julfilling and Sustainable Society," International Journal of Solar Energy, Vol. 17, No. 2-3, pp. 83-100, 1995.

Solow, R., "An Almost Practical Step Towards Sustainability," Resources Policy, Vol. 19, No. 3, pp. 162-172, 1993.

Stoett, P., "Global Environmental Security, Energy Resources and Planning: A Framework and Application," Futures, Vol. 26, No. 7, pp. 741-758, 1994.

Toman, M., "Economics and 'Sustainability:' Balancing Trade-offs and Imperatives," Land Economics, Vol. 70, No. 4, pp. 499-513, 1994.

Tonn, B., "Future Generations, Environmental Ethics, and Global Environmental Change," in T.

Kim and J. Dator (Eds.), Creating a New History for Future Generations, Institute for the Integrated Study of Future Generations, Kyoto, Japan, November, pp. 141-158, 1994. 
Tonn, B., "Philosophical Aspects of 500-Year Planning," Environment and Planning A, Vol. 20, p. $1512,1987$.

Tonn, B., "500-Year Planning: A Speculative Provocation" Journal of the American Planning Association, Spring, p. 186, 1986.

Tonn, B. and Peretz, J., "Institutional Issues and Subnational Environmental Decision Making," National Center for Environmental Decision-making Research Working Paper, University of Tennessee-Knoxville, Knoxville, TN, 1998.

Tonn, B. and Peretz, J., "Field Notes on Using Risk in Environmental Decision Making: Lack of Credibility All Around," Inside EPA's Risk Policy Report, Vol. 4, No. 6, pp. 33-36, 1997.

Tonn, B. and Petrich, C., Environmental Citizenship: Problems and Prospects, ORNL/NCEDR-1, Oak Ridge National Laboratory, Oak Ridge, TN, October 1997.

Tonn, B. and White, D., "Sustainable Societies in the Information Age," The American Sociologist, Vol. 27, No. 1, pp. 102-121, 1996.

Tough, A., "What Future Generations Need From Us," Futures, December 1993.

Valaskakis, K., Sindell, P., Smith, J. and Fitzpatrick-Martin, I., Tentative Blueprints for a Conserver Society in Canada, GAMMA, Montreal, 1975.

Wagenaar, W. A., and Timmers, H., "The Pond-and-duckweed Problem; Three Experiments on the Misperception of Exponential Growth," Acta Psychologica, Vol. 43, pp. 239-251, 1979.

Ward, B. and Dubos, R., Only One Earth - The Care and Maintenance of a Small Planet, New York: Norton, 1972. 
Wojcik, D., The End of the World as We Know It, New York: New York University Press, 1997.

World Commission on Environment and Development, Our Common Future, United Nations, NY, 1987.

Zachary, J., Sustainable Community Indicators: Guideposts for Local Planning, Community Environmental Council, Gildea Resource Center, Santa Barbara, CA, 1995. 